\title{
EL SUBGÉNERO TEATRAL DEL ROMANTICISMO RELIGIOSO ESPAÑOL: BALTASAR DE GERTRUDIS GÓMEZ DE AVELLANEDA
}

\author{
Miguel-Ángel Muro \\ Universidad de La Rioja
}

\section{RESUMEN}

Este artículo ofrece un análisis e interpretación del mejor drama de Gertrudis Gómez de Avellaneda, Baltasar, escrito en 1858, a partir del episodio bíblico de la Cena del rey Baltasar y la caída del imperio neobabilónico. El propósito de la autora -expresado en el prólogo de la obraera demostrar cómo la Providencia de Dios rige los destinos de los seres humanos y de sus imperios. El mayor atractivo y novedad de esta obra radican en presentar a Baltasar como un hombre consumido por el Hastío -la enfermedad literaria del siglo XIX-, enfrentándolo a la fe religiosa de dos muchachos judíos, Elda y Rubén, y de dos personajes históricos, el rey Joaquín y el profeta Daniel. La obra vendría a seguir la estela de Don Juan Tenorio, para configurar un subgénero teatral de romanticismo religioso conservador.

Palabras clave: Gertrudis Gómez de Avellaneda, Baltasar, Biblia, romanticismo religioso conservador

\section{THE THEATRICAL SUBGENRE OF THE RELIGIOUS SPANISH ROMANTICISM: GERTRUDIS GÓMEZ OF AVELLANEDA'S BALTASAR}

\begin{abstract}
This article offers an analysis and interpretation of the best Gertrudis Gómez de Avellaneda's drama, Baltasar, written in 1858, based on the biblical episode of the Dinner of King Baltasar and the fall of the neo-babylonian empire. Author's purpose — aforesaid in the piece's prefacewas to demonstrate how God's Providence governs man's destiny and his empires. The greatest attraction and novelty of this piece lies in showing Baltasar as a man ruined by Spleen - the nineteenth century's literary disease-, confronting his lack of religious faith to the faith of two Jewish young people, Elda and Rubén, and two historical characters, King Joaquin and prophet Daniel. This drama would follow the wake of Don Juan Tenorio, and would contribute to a theatrical subgenre of religious conservative romanticism.
\end{abstract}

Key words: Gertrudis Gómez de Avellaneda, Baltasar, Bible, religious conservative romanticism. 
Después de la copiosa y fructífera presencia de la Biblia en el teatro español de la Edad Media y el Barroco, la escena ilustrada y el romanticismo recurrieron en menor medida a esta fuente de inspiración. Los nuevos tiempos ilustrados, que fiaban a la Razón y a la actividad crítica la explicación y el desarrollo del mundo y del ser humano, no eran los más propicios a su dimensión religiosa. Y el romanticismo, que sí la entendió y la acogió, fue más favorable a misticismos vagos y paganizantes y, sobre todo, a sustituir a Dios por el amor humano vivido como una religión, que a la asunción de una religión cristiana oficializada. El dios cristiano es sustituido en la nueva sensibilidad por una naturaleza divinizada o por alguna divinidad grecolatina, o aparece con frecuencia mezclado con nociones que le son ajenas, como las del destino, el hado o la fortuna, que sustituyen a la de providencia divina; el ser amado, por otra parte, viene a ocupar el lugar de Dios en numerosas obras muy representativas, desde el primer romanticismo. Por el contrario, el romanticismo conservador prefirió revitalizar la creencia religiosa cristiana, recurriendo a procedimientos que pusieran de manifiesto la grandeza de Dios y sus designios; la Biblia suponía, a este respecto, un excelente caudal de historias edificantes, investidas de la autoridad propia de un libro sagrado.

En el romanticismo español y, más en concreto, en su teatro, hay que esperar hasta la segunda mitad del siglo XIX para que la arreligiosidad o la irreligiosidad dejen paso a un rearme religioso cristiano. La obra fundamental en este proceso es, sin duda, el Don Juan Tenorio de Zorrilla, estrenada en 1844. Del Don Álvaro del Duque de Rivas (1835), obra representativa del primer romanticismo español, al Don Juan, el cambio es sustancial y evidente. En el primero, es el fátum el que señorea de forma caprichosa y cruel los destinos de los personajes ${ }^{1}$, mientras que en el segundo, es el designio del Dios cristiano el que rige la vida, la muerte y la salvación de su irreverente y blasfemo protagonista, a través de la intercesión de su amada, o mejor, de la mujer que lo ama.

Ya dentro de esta corriente ideológica propicia a la revitalización religiosa cristiana, Gertrudis Gómez de Avellaneda dedicó a mediados del XIX lo más sustancial y consistente de su quehacer teatral a dos recreaciones de motivos bíblicos, con los dramas² Saúl (1849) y Baltasar $(1858)^{3}$, compues-

\footnotetext{
${ }^{1}$ Mesonero Romanos subraya la importancia y riesgo del fatalismo en esta composición («... lo arriesgado de la idea primordial del fatalismo que campeaba en el drama...» (2008: 590).

${ }^{2}$ Para la autora (y para el público y crítica, en general), la denominación subgenérica «drama» venía a equivaler, en obras de este tipo, a la de «tragedia» (GARCÍA LORENZO,1967), sin mayor reflexión teórica sobre el asunto. De hecho, en la advertencia o prólogo de la autora a Saúl, filia su obra con las tragedias de Alfieri y Soumet y en la «Nota» con que termina ese texto preliminar habla de «tragedia». (GÓMEZ DE AVELLANEDA, 1869 : 214). Narciso Alonso Cortés — conocedor como pocos del teatro español de la época- las considera «tragedias» y como tal las estudia. (1968: 284-286). No obstante, su ar-
} 
tos desde la creencia religiosa y con una clara intención ideológica, como explicita en la Dedicatoria que dirige a S.A.R. el príncipe Don Alfonso de Borbón.

Baltasar acude a la Biblia para presentar el drama del último emperador del imperio neobabilónico que, corroído por un hastío vital invencible, cree encontrar en dos jóvenes judíos cautivos la razón para vivir; en Elda, el amor y en Rubén, la valentía movida por la creencia. Cuando sale de su error, ya que ambos están casados y comparten con pasión el deseo de libertad de los judíos, deja que el pueblo asesine al muchacho y que Elda se precipite en la locura, mientras él mismo busca la muerte luchando contra los persas invasores. Antes de expirar reconocerá la grandeza del Dios de los judíos, ante su madre, el rey judío Joaquín y el profeta Daniel, quien vaticinará la llegada de Cristo.

\section{EL ROMANTICISMO RELIGIOSO}

Entiende Gies (1997: 311) que «Gómez de Avellaneda creó un género teatral que puede llamarse 'Romanticismo religioso' por integrar los dominantes motivos románticos dentro de un mundo marcado no por la angustia romántica sino por el sentimiento religioso.» Así es, pero conviene precisar que no se trata tanto de una creación (porque ya había sido puesto en pie por Zorrilla), cuanto de subrayar el componente religioso de la fórmula, que, ciertamente, vendría a dar réplica y solución a la angustia romántica bien patente en sus dos héroes, Saúl y Baltasar.

Por otro lado, considera también Gies que la autora estaría tratando con Saúl y Baltasar de resucitar el espíritu trágico del primer romanticismo, si bien desde una perspectiva religiosa, algo que vendría favorecido por el éxito del

gumentación queda en un escueto «por su fondo y desenlace [es] una verdadera tragedia», refiriéndose, en particular, a Baltasar. Tampoco llega a ser convincente la argumentación de González Subías (2005) a favor de la existencia de una «tragedia romántica», distinta y superadora de la «tragedia neoclásica y del «drama romántico». D. L. Shaw entiende que «Los dramas románticos [...] no son tragedias en el sentido estricto del término, ya que las fuerzas en conflicto no son nunca iguales. Al hombre siempre se lo ve luchando contra fuerzas (tiempo, destino, perversidad de las cosas, injusticia cósmica) que no puede esperar derrotar.» (1997: 321); pero es que no puede entenderse la tragedia sin una fuerza invencible, como el destino adverso señalado por los dioses, y sin que ante ella se alce la voluntad del héroe de resistirlo a sabiendas de su fracaso seguro.

${ }^{3}$ De hecho, ambos dramas fueron éxitos importantes en su momento y vienen gozando del aprecio de la crítica desde entonces; vid. COTARELO Y MORI, 1930: 65; ARROM, 1944; ALONSO CORTÉS, 1968: 284-286; RUIZ RAMÓN, 1979: 334; LEAL, 1980; GIES, 1996: 280 y 285 y DOMÉNECH, 2003:1936. Sobre las vicisitudes de la aceptación de la autora en el canon de «Alta Cultura» isabelina y su exclusión con el cambio de 1868, puede verse el artículo de SÁNCHEZ-LLAMA (2001). 
Don Juan Tenorio de Zorrilla. Pero, de nuevo, es necesario precisar que, si trató de resucitarlo fue para mejor volverlo a enterrar, una vez representada su derrota y, por otro lado, que Saúl y Baltasar son dos obras distintas, por la índole de sus héroes y por su final. Baltasar encarna al hombre consumido por el hastío (que ya se apuntaba, como posibilidad, en La nueva Eloísa y que cuajará de forma espléndida como componente medular de la modernidad literaria con Baudelaire ${ }^{4}$ ), mientras que Saúl responde al prototipo romántico de hombre volcánico. El final de Saúl y el de Baltasar son, además, muy distintos en cuanto a la enseñanza religiosa que se pretende transmitir; de hecho, Saúl miraría más, en este sentido, a El estudiante de Salamanca, y con él al titanismo blasfemo, mientras que Baltasar lo haría al Don Juan Tenorio.

Conviene no olvidar, a este respecto, la complejidad de la visión del mundo romántica o, por mejor decir, la complejidad del movimiento artístico romántico que la refleja y realimenta. En este sentido es útil distinguir entre el romanticismo liberal, progresista o subversivo y el histórico, conservador o reaccionario; pero quizá sea más útil todavía asumir que ninguna de las dos manifestaciones puede arrogarse el derecho de ser la «genuinamente» romántica, ya que ambas son respuesta a la crisis de la época ${ }^{5}$, y para el caso particular de Baltasar, que una misma obra puede acoger influencias contrapuestas.

\section{LA COMPLEJIDAD DEL MENSAJE IDEOLÓGICO DE BALTASAR}

Baltasar utiliza los mismos elementos que los dramas románticos subversivos con unas relaciones distintas entre ellos, y con una finalidad opuesta: la de «llenar el corazón de piedad cristiana» ${ }^{6}$.

En realidad, Baltasar estaría tomando la fórmula romántica subversiva del primer romanticismo para desactivarla, oponiéndole la solución religiosa. La utilización del patrón bíblico, unido a la fórmula dramática romántica más reconocible (la del romanticismo subversivo) y virado hacia el Don Juan, hace de Baltasar una obra compleja y tensionada, con fuerzas que no actúan en la misma dirección.

${ }^{4}$ Es interesante tener presente que Las flores del mal se publican en 1857 y que el Hastío es en la poesía de Baudelaire el tema fundador, como consecuencia de una sensibilidad poética que vive con deleite morboso el vacío y la impotencia del espíritu al borde de la Nada.

${ }^{5}$ Por eso son discutibles apreciaciones como las de Caldera, cuando considera que $L a$ conjuración de Venecia es un drama que pertenece a una época en la que el teatro clásico acoge componentes propios del Romanticismo, pero «no siempre su verdadero espíritu» (SHAW, 1997: 322 y remite a CALDERA, 1974: 119)

${ }^{6}$ Como expresó con claridad el ideólogo pionero de este rearme espiritual, Bölh de Faber al animar a los autores a hacer «cuanto es menester para llenar el corazón de piedad cristiana, satisfacer la razón con sana doctrina y divertir el entendimiento sin peligro.» (Crónica Científica y Literaria, número 3, Madrid, 1817; cit. en CARNERO, 1990: 125). 
Baltasar se opone, ciertamente, a la fórmula dramática básica de los principales dramas románticos españoles (La conjuración de Venecia Don Álvaro, Macías, El Trovador, Alfredo o Los amantes de Teruel), que supone la exaltación del amor humano a la más alta justificación de la vida, y el choque de este amor, vivido con éxtasis religioso, contra un destino fatal que lo arrasa, (destino sustanciado, antes que nada, en contrariedades de tipo social), produciendo en los amantes el dolor, la desesperación y la muerte (Herrero, 1988); ni este amor, ni el destino fatal tienen cabida en Baltasar, ya que el amor ha de ser sancionado por la religión, y el Dios bíblico (y después cristiano) y su Divina Providencia sustentan y justifican el orden del mundo y de la historia individual y colectiva, y la creencia religiosa ha de bastar para aceptar sus designios.

La Avellaneda presenta el amor humano (el del rey por Elda) como la fuerza vital por antonomasia, la única capaz de dar sentido a la vida del monarca (aunque ya hay que notar que en esta obra no se presente con el extremismo de la adoración religiosa, mística, propio de las obras del primer romanticismo); pero la Avellaneda presenta este amor como equivocado e imposible de raíz, por producirse entre dos seres de distinta creencia; y sin embargo, el efecto de esta pasión de Baltasar, al ser contrariada, es el de las obras más representativas del romanticismo liberal, al acarrear el sufrimiento y la muerte de los protagonistas. La pasión de Baltasar por Elda no es recíproca, frente a lo que ocurre en aquellos dramas, y esto es un atentado cabal contra la esencia del programa romántico, porque desactiva el amor, la pasión, como la verdadera razón de ser de la vida y motor del mundo, e instala en su lugar al amor sancionado por la iglesia con el matrimonio; Baltasar se entrega a la muerte, en una actitud que se acerca al suicidio, pero antes reconoce la grandeza de Dios, con lo que se engrandece el valor religioso. La pareja héroe-heroína románticos, vinculados por un amor sublime, aquí se rompe o, mejor, no llega a darse: Elda ama a Rubén y no cabe ni el menor atisbo de amor por Baltasar. Así los dos muchachos hebreos se convierten en víctimas, pero no de su amor, ni por el destino adverso, sino de una entidad más compleja (amor-conciencia política-fe en Dios), algo que ya no coincide con el planteamiento religioso genuino.

El final de Elda, enajenada, no tiene su justificación en una denuncia contra un mundo radicalmente injusto o un destino funesto, sino en el trastorno causado por la muerte atroz de su amado esposo y en el deseo de la Avellaneda de ofrecer un tópico romántico a sus espectadores. El motivo principal de la obra, además, es mostrar la caída de un imperio por designio divino, con lo que la dimensión del drama pasa de lo personal a lo social y lo político, algo que en los dramas españoles citados no se produce.

Con respecto al hastío vital — componente capital de la fórmula teatral del romanticismo subversivo - no cabe duda de que fue un gran acierto de la Avellaneda el configurar al protagonista de su drama como un romántico, 
como un ser devorado por un vacío de creencias e ilusiones, de razones para vivir, que le hacen soportar con desgana la existencia ${ }^{7}$. En la cima del poder desde su nacimiento, no columbra nada que pueda desear o que se le oponga que no le esté ofrecido y doblegado sin el menor esfuerzo por su parte. Avellaneda — siguiendo el esquema del romanticismo liberal— dejará entrever a Baltasar cómo el amor puede dar sentido a la vida, para —usando de la ironía romántica- despeñarlo de la recién inaugurada felicidad al abismo de la soledad y el desengaño, al saber que su amada ya está casada y, además, es imposible que corresponda a su amor.

Hecho fundamental en aquellos dramas es el que el protagonista sea una víctima inocente; en Baltasar, sin embargo, el rey está en una situación algo ambigua: es culpable en cuanto déspota impío, pero es inocente en su amor por Elda y su admiración por el valor de Rubén; volvería a ser culpable cuando, en su despecho y desengaño, permite el asesinato del muchacho, causa la locura de Elda, sigue negando a Dios y comete sacrilegio con sus vasos sagrados.

En esta obra, como no puede ser de otro modo, con el patrón bíblico a su base, el Destino ha sido sustituido por la Providencia (cuyo camino, además, venía trazado por la Biblia y era voceado por los profetas). Esta exaltación de la grandeza del Dios y de su Providencia hacen más fácil a la Avellaneda seguir a Zorrilla en el último quiebro (un salto mortal), en el que el protagonista reconoce la grandeza de Dios; como en Don Juan el protagonista alcanzaba esta gracia por intercesión de doña Inés, aquí lo logrará por las súplicas de Joaquín.

En la sustitución del destino por la Providencia también hay complejidad. El destino es una entidad importantísima en el teatro romántico (como lo fue antes en la tragedia, desde los griegos). Entendido, en líneas generales, como una fuerza maléfica que traza el camino de los seres humanos y los encamina inevitablemente hacia el sufrimiento y la muerte, los griegos lo hacían depender de los designios de los dioses. Los románticos subversivos, retirada la idea de Dios y de cualquier dios de su visión del mundo, privan a la adversidad devastadora de cualquier explicación causal, lo que la hace más aterradora. En Baltasar este destino es sustituido por la Providencia y, así, aunque sus efectos son igualmente fulminantes para Baltasar, Nitocris, Elda y Rubén, se salva la idea de existencia de un Principio explicativo, de un designio que actúa detrás del sufrimiento y le da justificación (como castigo divino, para el rey, aunque luego sea agraciado con la revelación de la gran-

${ }^{7}$ De hecho, parece configurado para ejemplificar la situación espiritual romántica descrita por Pastor Díaz, «en que el mundo de la inteligencia es el caos, el del sentimiento el vacío; en que el hombre no ejercita su pensamiento sino en el análisis y en la duda y no conserva su corazón sino para sentir la soledad que le rodea y el abismo de hielo en que yace.». (PASTOR DÍAZ, 1905, I, p. 9; en SHAW, 1997: 329). 
deza de Dios) y, además, se abre a la esperanza, por la idea del sacrificio (para Elda y Rubén, a favor de su pueblo y de su fe). Si, como expresa Casalduero: «El cadáver romántico es un testimonio de la falta de sentido de la vida»; 1951: 29; (en Shaw, 1997: 327), Avellaneda se esforzó porque el de Baltasar fuera justamente un ejemplo de la acción de la providencia divina.

Bien vista, no obstante, la ausencia de dios no debería, necesariamente, traer aparejada la angustia: también cabría la posibilidad del hombre engrandecido y libre en su falta de tutela: el romántico tendría que ver en la nueva ideología la situación propicia para el hombre sentimental y libre. Pero, evidentemente, nuestro teatro romántico no comulgó con esta forma de ver las cosas. Así el romántico liberal, ante las adversidades profundas, el dolor y la muerte, bien puede no llegar a prescindir de Dios, sino contentarse con barajar las entidades de Dios y del destino a conveniencia, para hallar una explicación o plantear una denuncia ${ }^{8}$. Más que perpetrar un deicidio y mostrar un mundo sin Dios, lo que intentaría entonces es llevar a cabo una crítica a la noción de Dios amparada por el despotismo y el conservadurismo reaccionario y, a su vez, sustentadora de sus privilegios. No es tanto que el romanticismo liberal español subraye esta faceta angustiosa de un mundo sin dios ni providencia, cuanto que, no siendo verdaderamente radical, muestra la falta, la necesidad de una instancia superior a la que apelar (y culpar) cuando fallan sus expectativas de mejora individual y social. Desde aquí, ciertamente, este romanticismo puede ir a la raíz (de forma sincera o como pose teatral) y hacerse preguntas trascendentes, metafísicas, sobre el Mal y hacer responsable de él al destino, faltos de un Dios al que hacer responsable o por falta de atrevimiento para culparlo abiertamente de él.

En cuanto al Mal, a la maldad humana, la que anida en el corazón de los hombres, y a la maldad cósmica, en Baltasar también el asunto es complejo, frente a la claridad de posturas de la fórmula dramática romántica genuina. En este drama, la oposición entre Mal y Bien se produce en el interior del mismo personaje protagonista. En principio, el mal provendría de Baltasar, que mantiene en esclavitud al pueblo elegido de Dios, pero esa actuación se trueca en bondad por el amor para, justamente entonces, cuando desea la vida y dar amor y liberar al pueblo de Dios, recibir el golpe doloroso de la Providencia, lo que lo lanza a una dinámica de destrucción de la que él mismo pasa a ser víctima. $\mathrm{Y}$ es que lo que verdaderamente encarecen las obras del primer romanticismo español es la fortaleza cruel de una sociedad inmovilista y reaccionaria, con sus imposiciones injustas, contra la que valores sustanciales admitidos por los románticos, como la libertad y la pasión (y un cierto nuevo orden social, correspondiente al hombre nuevo), se estrellan y salen derrotados, donde al idealista sólo le cabe el papel de víctima.

\footnotetext{
${ }^{8}$ Algo que ya puede verse en La nueva Eloísa, texto fundacional de la nueva sensibilidad.
} 
En cuanto a la solución de esta lucha entre el destino y el héroe, el suicidio es la decisión drástica. Este Romanticismo pone en pie a un héroe para el amor y el sufrimiento; como el de la tragedia griega, se enfrenta a fuerzas que lo rebasan, nombradas como destino, pero, para el romántico, este destino, primero, ya tiene mucho de fuerza de la estructura social y, segundo, ya no es adjudicable a los dioses; la grandeza humana que pone de manifiesto la tragedia tiene que ver con la serenidad con que el héroe acepta su dolor o su muerte, como propias de un orden superior al que debe inmolarse; falto ese orden superior, el romántico se da muerte desesperado, sintiéndose una víctima de las imposiciones de la sociedad, del odio de otros hombres y, por extensión (o por elevación), del mal cósmico ${ }^{9}$. El suicidio del romántico puede leerse como un fracaso radical o como una inmolación heroica para demostrar lo pernicioso de un estado de cosas aberrante para el ser humano, como la victoria del ser libre y apasionado, que toma la decisión más trascendente, la de privarse de la vida, como una bofetada antisocial y antirreligiosa.

\section{POSIBLES FUENTES DE INSPIRACIÓN PARA EL BALTASAR}

Parte de la explicación de esta configuración del Baltasar se encuentra en las obras de las que la Avellaneda pudo recibir influencia a la hora de escribir su drama. En cuanto a la atractiva decisión de hacer de Baltasar un monarca hastiado, cabe recordar que la figura del rey neurasténico gozaba de favor en la poesía francesa del momento, con textos como «Le roi solitaire», de Gautier, «El mago», de Esquiros, o aquel a quien se compara la voz poética de «Spleen» de Baudelaire ${ }^{10}$. Dando por supuesto que el Don Juan Tenorio le ofreció lo medular de la fórmula teatral, viene siendo discutida la influencia que pudo tener el Sardanápalo de Byron $^{11}$ en el Baltasar de la

\footnotetext{
${ }^{9}$ «...el héroe romántico —entiende Shaw- [...] es en esencia una víctima. ¿De la sociedad? Sí. ¿Del mal que los hombres se hacen unos a otros? Sí. Pero por encima de todo es una víctima del destino, de un mundo diabólico, de situaciones que no tienen nada que ver con una interpretación armoniosa de la condición humana. Como ya expusimos al principio, hoy tendemos a ver al héroe romántico como una víctima de la crisis ideológica y espiritual de la época, una crisis que supuso el derrumbamiento de unos valores que antes eran totalmente aceptados, ya descansaran en la religión o en el racionalismo. Su desesperación era una desesperación existencial.» (1997: 324).

${ }^{10}$ «Yo soy como aquel rey de un lluvioso país,/ rico, mas impotente; joven y ya muy viejo,/ que, de sus preceptores las venias despreciando,/ se aburre con sus perros cual con las otras bestias. Nada alegrarle puede, ni el halcón ni la caza,/ ni su pueblo que muere delante del balcón./ Del bufón favorito la balada grotesca/ ya no distrae la mente de este enfermo cruel;/ flordelisado el lecho en tumba se convierte,/ y las damas, que a todos los príncipes ven bellos, no saben encontrar un atavío impúdico/ que arranque una sonrisa del joven esqueleto.» (Baudelaire, 1995: 303).

${ }^{11}$ Ver Carlos M. RAGGI (1981).
} 
Avellaneda, quien en la etapa de composición de su obra leyó al romántico inglés en una traducción al castellano. Parece aceptable que pudiera darle la idea de la composición de un drama «oriental», con el final de un imperio como motivo básico ${ }^{12}$. En cuanto a la caracterización del personaje protagonista, el Sardanápalo de Byron presenta al emperador asirio dado al placer como razón suficiente y fundamental de su vida, si bien, capaz asimismo de mostrar valor y altivez al defender su reino de las intrigas internas y de los invasores externos; Baltasar es presa del hastío, pero también terminará su vida luchando con valor contra los invasores enemigos. A su lado, Salamenes, su cuñado, se alza como figura vigorosa, defensor de la integridad moral y de las virtudes propias del gobernante y jefe de los ejércitos, como en Baltasar hará la reina madre Nitocris.

Estructuralmente y en algunos motivos temáticos hay más coincidencias de las que se muestran, si se consideran las dos obras en general o en un vistazo global, como se ha venido haciendo.

En ambas, por ejemplo, se produce la presentación indirecta del protagonista, hecha, además, por dos personajes adversos o críticos con él; en Baltasar la hace el profeta Daniel, mientras que en Sardanápalo queda a cargo de Salamenes, su valeroso y severo cuñado. Tras ella, el protagonista se presenta subrayando los rasgos que lo definen, para pasar a continuación a mostrarse con mayor matiz obligados por un debate serio y bien nutrido de argumentos; el papel de Salamenes, reconviniendo al rey, pasa a ejercerlo en Baltasar Nitocris, personaje que parece creado a inspiración del byroniano. En este debate, además, hay motivos coincidentes entre los dos dramas como, por ejemplo, la responsabilidad del gobernante o, con mayor precisión, la contraposición entre la fama guerrera y el tributo en vidas de súbditos que hay que pagar por ella; también hay coincidencia entre Sardanápalo y Baltasar en el desapego religioso y, en otro orden de cosas, en la facilidad y rapidez con que ambos abandonan lo que parecía ser una inamovible actitud vital, pasando Sardanápalo de la molicie y un cierto filantropismo al ardor guerrero, y Baltasar, del escepticismo radical, al amor, al desengaño y a la búsqueda de la

\footnotetext{
${ }^{12}$ Alonso Cortés afirma que «Parece probable que la lectura de Sardanápalo, de Lord Byron, sugiriera a la Avellaneda la idea de su drama; pero entre uno y otro no hay verdadera semejanza.» (1968: 285). También Bravo-Villasante desdeñaba esta influencia: «El tema - escribió- podrá ser de Byron, ya que escribió una obra con el mismo nombre [sic], pero el espíritu es de Calderón y españolísimo» (1967: 198). Esta vinculación del Baltasar con La vida es sueño me parece, no obstante, forzada y falta de argumentación convincente: «Baltasar, como Segismundo pasa del sueño a la vigilia. Cuando atiende a Elda y tiene la revelación del hombre virtuoso está despierto y su corazón siente, cuando la desoye vuelve a ser el apático pagano. Alterna la esperanza y la desesperanza, el paganismo y el cristianismo. La Avellaneda describe a Baltasar 'como despertando de un sueño penoso', y a la manera de los famosos monólogos de Segismundo, en que se considera la vida como frenesí pasajero e ilusión, Baltasar también monologa desilusionado» id.). También Villaverde (1981: 203) abunda en la vinculación de Baltasar con Calderón (y Cervantes).
} 
muerte en la batalla. Ambos personajes, por otro lado, desdeñan los indicios de amenaza (las asechanzas de los traidores, Sardanápalo; la invasión de los medos y persas, Baltasar), con mayor riesgo de inverosimilitud en la obra de Gómez de Avellaneda. Cabe también la posibilidad de que a la Avellaneda se le ocurriera el personaje de Elda, al ver el de Mirra en Sardanápalo, y que el banquete en que se empeña Sardanápalo (y en cuyos prolegómenos suena algún trueno intranquilizador), le trajera a la memoria a la autora el festín bíblico de Baltasar. Y, aunque tenía ejemplos más que suficientes en otras obras románticas, también pudo hallar inspiración Avellaneda para su escena de delirio de Elda, en el sueño tétrico de Sardanápalo después de la primera batalla. También en ambas obras hay una pareja de conspiradores: Arbaces y Beleses, en Sardanápalo, y Rabsares y Neregel, en Baltasar. Todos ellos del círculo más próximo al rey y traidores; la entidad, no obstante, de estos personajes es muy desigual en ambas obras: en la de Byron son personajes con peso, de presencia y palabra vigorosas, mientras que en la de Avellaneda no pasan de ser dos intrigantuelos endebles, sin llegar a adquirir verdadera dimensión dramática. Beleses, además, es sacerdote o adivino: profeta, cabría decir también, como Daniel en Baltasar; porque la diferencia entre el adivino y el profeta, entre el que cree en los dioses o en Yaveh, en el destino o en la Providencia divina, sólo estriba en la fe, en la diferencia de fe.

Si para el desenlace de Baltasar (y, por tanto, para su orientación ideológica) Avellaneda va a seguir a Zorrilla; hará lo propio con Espronceda y $\mathrm{El}$ estudiante de Salamanca (publicada en 1840, aunque compuesta unos años antes) para la configuración de su personaje protagonista y para parte de la andadura que lo muestra, aunque la vitalidad desesperada y agresiva de don Félix de Montemar esté lejos de la indolencia hastiada de Baltasar; puede conjeturarse también que para la locura de Elda la Avellaneda pudiera tener presente la de Elvira («que es la razón un tormento,/ y vale más delirar/ sin juicio, que el sentimiento/ cuerdamente analizar,/ fijo en él el pensamiento.» (1975: 105), aunque también es verdad que, tratándose El estudiante de una obra que acoge motivos anteriores, la autora podría muy bien haberlos tomado del aire del tiempo. Pero lo cierto es que la lectura de algunos de los pasajes más significativos de la obra de Espronceda viene a dar la mayor parte de la columna vertebral del Baltasar:

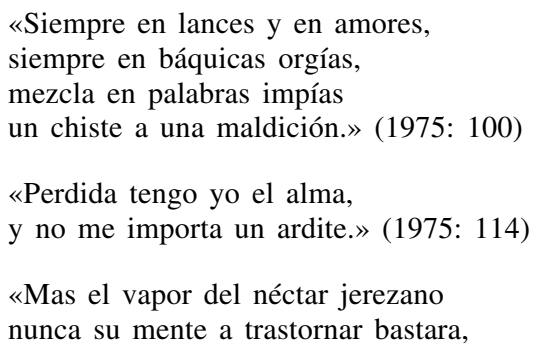


que ya mil veces embriagarse en vano

en frenéticas orgías intentara.» (1975: 125)

«Dejad ya, don Félix, delirios mundanos.

— ¡Hola, me conoce! — ¡Ay! ¡Temblad por

[vos!

¡Temblad no se truequen deleites livianos

en penas eternas! — basta de sermón,»

(1975: 130)

«Grandïosa, satánica figura,

alta la frente, Montemar camina, espíritu sublime en su locura,

provocando la cólera divina:

fábrica frágil de materia impura,

el alma que la alienta y la ilumina,

con Dios le iguala, y con osado vuelo

se alza a su trono y le provoca a duelo.»

(1975: 139)

Junto a estas posibles influencias (que vendrían a recoger el espíritu del primer romanticismo), Gómez de Avellaneda decide tomar de la Biblia el famoso episodio del festín sacrílego del rey Baltasar para recrearlo en su «drama oriental ${ }^{13} \gg$ : decisión bien marcada en lo ideológico, ya que la Biblia ofrece este pasaje para mostrar la grandeza de Dios, manifestada a través de la capacidad adivinatoria e interpretativa de su profeta, que señala el fin del imperio neobabilónico a manos de los persas y medos, al tiempo que, por supuesto, da justificación y explicación al mundo por sus designios y providencia, arrumbando al hado y privando de sentido a la angustia existencial ${ }^{14}$.

\footnotetext{
${ }^{13}$ Gómez de Avellaneda nombra a Saúl «drama bíblico» y a Baltasar «drama oriental», sin que en sus prólogos o dedicatorias explique el porqué de esta diferencia. Ambos están basados en episodios bíblicos y, lo que es más importante, escritos desde una lectura cristiana de la Biblia, «sin — como dice la autora—alteración considerable de la verdad bíblica» (1869a: 213). Quizá la diferencia para la autora estribase en el hecho de haber inventado para el segundo varios personajes babilónicos (Nitocris, Rabsares, Nerengel...), mientras que en Saúl los personajes corresponden al pueblo hebreo.

${ }^{14}$ El Libro de Daniel ya había servido de inspiración a Hilario de Poitiers, discípulo de Pedro Abelardo, para su composición Historia de Daniel representanda que muy posiblemente estuviera en el origen del Ludus Danielis, compuesto por alumnos de la escuela catedralicia de Beauvois. (GÓMEZ MORENO, Ángel. La teoría teatral en la Edad Media». En Huerta Calvo, Javier (dir.) p. 102 y 214). En el Código de Autos viejos (en Huerta Calvo, Javier (dir.), p. 390), el XIV es el Auto del rey Nabucodonosor cuando se hizo adorar. Mercedes de los Reyes Peña lo clasifica como «sin valor prefigurativo explícito, sin referencias eucarísticas; y hay también otro, el XV: Auto del sueño de Nabucodonosor (con valor prefigurativo explícito o apuntado, sin referencias eucarísticas, p. 395). Pero fue Calderón de la Barca el que convirtió al rey Baltasar en protagonista de un auto sacramental desempeñado por el propio monarca y el profeta Daniel, y las figuras alegóricas del Pensamiento de Baltasar, la Vanidad, la Idolatría y la Muerte, con la intención de poner de relieve o
} 
El DRAMA DE LA AVEllanedA: LECTURA DE LA AUTORA

Con el telón de fondo del romanticismo en el que podrían destacarse estas obras y su influencia, Gertrudis Gómez de Avellaneda traza un drama en el que dispone el enfrentamiento entre la visión romántica desesperanzada, atea o blasfema y la que ve en el cristianismo la explicación y justificación de todo lo humano.

La propia autora explicitó la inspiración y los objetivos de su obra en la dedicatoria que dirigió a S.A.R. don Alfonso de Borbón, hablando de cómo intentó «encerrar en las estrechas dimensiones de una composición teatral un gran pensamiento filosófico.» (1869b: 297), consistente en mostrar la caída del imperio babilónico — señalada por el llamativo prodigio de la mano que escribe tres voces enigmáticas en el revocado del muro del palacio de Baltasar-, como la prefiguración de la ruina de todo el mundo antiguo y advenimiento «del día eterno de la verdad» (1869b: 296), y el festín sacrílego de Baltasar como «el gráfico sello de una civilización materialista.» (1869b: 297). La historia de la humanidad se presenta para Gómez de Avellaneda, siguiendo al Libro de Daniel, como una progresión providencialista, en la que la caída de los grandes imperios del mundo antiguo, hasta la unificación producida por el imperio romano, no son sino pasos prefigurados por Dios para que el cristianismo pudiera iluminar a toda la humanidad.

También Gertrudis Gómez de Avellaneda expuso con claridad y pormenor el «carácter y el pensamiento» de su drama. En él la figura principal es un rey Baltasar — «representante del despotismo de los reyes paganos, á par que de la corrupción é impotencia de una sociedad caduca» (1869b: 299)_ configurado a la romántica como un déspota devorado por el hastío de la vida entre todos los goces materiales y las pompas de la vanidad, un alma sin dios, soberbia y solitaria. No deja de ser irónico que este Baltasar, presentado como emblema de una sociedad caduca, tenga rasgos del héroe romántico subversivo, justamente el que se opone a una sociedad burguesa de valores caducos, entre los que se encuentra, por supuesto, la religión, como creencia anquilosada y sustentadora de las injusticias sociales y de las diferencias de clase y condición que impiden el amor de los amantes.

A este personaje, Gómez de Avellaneda no enfrenta directamente al profeta Daniel, sino a dos personajes inventados, Rubén — nieto del rey Joaquín, que yace prisionero en una mazmorra - y Elda — joven ahijada de Joaquín y prometida de Rubén-. Quiere la autora que ambos sean representantes de lo más bajo y abyecto del mundo antiguo: el esclavo y la mujer, para que así resalte mejor el contraste y sea mayor la ejemplaridad. Así, en ellos encon-

manifiesto en qué poco paran la vanidad y la idolatría cuando Dios lo dispone así y llega la muerte y cómo, bien lejos del banquete sacrílego del rey, se ha de adorar a Dios en la Eucaristía. 
trará Baltasar la dignidad y el amor que creía inexistentes en el mundo, hallazgo que hace volver a latir su corazón con ilusión y esperanza, si bien sólo para caer en un desengaño mayor al saber que Elda, de la que se ha enamorado, no es la hermana, sino la prometida de Rubén: relación que ambos pagarán cara, el muchacho con su muerte a manos del populacho y Elda con la locura. Este desengaño — tan romántico- precipita a Baltasar en la orgía como medio para remediar su vacío, en la cual cometerá el sacrilegio que dará lugar al prodigio interpretado por Daniel como anunciador de su caída. El rey, moribundo, admitirá la grandeza del Dios de los judíos, mientras Joaquín pide el perdón divino para él y Daniel profetiza la libertad del pueblo oprimido, la reconstrucción del Templo y el advenimiento del Mesías. La entrada de los persas victoriosos en el palacio real en llamas, pone fin al drama. Y finaliza la autora dejando bien asentado cuál es el fin ejemplarizante al que debe llegarse: la exaltación de la grandeza de Dios, único capaz de dar sentido a la vida humana y a sus formas de gobierno ${ }^{15}$.

\section{LA CONFECCIÓN DEL DRAMA CON VISTAS A SU MENSAJE RELIGIOSO}

\section{LOS PERSONAJES: BALTASAR Y SUS OPONENTES EN UN DEBATE IDEOLÓGICO- RELIGIOSO}

Sobre el conocido pasaje bíblico de la cena del rey Baltasar, Gómez de Avellaneda configura un personaje del rey Baltasar distinto del que presenta la Biblia y más complejo; al disponerlo, además, en el flujo temporal de la anda-

\footnotetext{
15 «Baltasar - representante del despotismo de los reyes paganos, á par que de la corrupción é impotencia de una sociedad caduca - no es, sin embargo, en mi obra un personaje de repugnante odiosidad. He querido pintar en él lo poco que es la más grande alma cuando no la ilumina la fe ni la fecunda el amor; y en el instante supremo en que se consuma la expiación, un rayo de claridad celeste viene á alumbrar aquella alma descreída, arrancando al arrepentimiento el gemido que no desoye nunca la inagotable/ clemencia. Joaquín extiende sus manos sobre la cabeza del sacrílego moribundo, perdonándole en nombre del Dios de Abraham, del Dios único universal... y resonando todavía aquellos ecos de misericordia sobre la tumba del escéptico — que proclama en su último suspiro la justicia de Dios y la dignidad del hombre - se alza el inspirado acento del profeta, anunciando entre las ruinas de la civilización arrollada por el soplo divino, la libertad del pueblo escogido y la reedificación del templo en que será promulgada la nueva ley de gracia, que, rompiendo las cadenas de los pueblos y disipando las sombras de la idolatría, hará santa la potestad y gloriosa la obediencia» (1869b: 298). Con declaraciones tan explícitas y sin nada sustancial que se derive de la lectura de la propia obra, se me hacen arriesgadas las lecturas de Baltasar en clave abolicionista, como la del artículo de Fabián Gutiérrez (1995); mucho menos aceptables considero las apreciaciones de Susanne Banusch (1996) en su lectura en clave psicoanálitica de la obra, por lo indemostrable de la argumentación.
} 
dura dramática, lo pone en situaciones que le permiten mostrar distintas facetas de su personalidad y evolucionar en su visión del mundo y sus afectos.

Sin lugar a dudas, el rasgo más llamativo y original del Baltasar de Gómez de Avellaneda es el hastío de la vida ${ }^{16}$ en que se consume, sin que parezca que nada ni nadie pueda aliviarlo; hastío que supone más una especie de ataraxia o de fastidio que una angustia punzante. Gómez de Avellaneda convierte a Baltasar en su protagonista, con la precaución y el acierto de no caer en la tentación de hacer del emperador un ser simple y un mero espantajo representante del mal ${ }^{17}$. Lo configura de forma muy consciente con aquellos rasgos que convienen a su designio ideológico y que expone con claridad en la Dedicatoria a D. Alfonso de Borbón: un tirano, hastiado del mundo y cuanto pueda ofrecerle en lo material, en lo espiritual y lo afectivo, ateo, en el culmen de la vanidad y de la soberbia, convencido de su superioridad sobre todo ser humano, a quien desprecia cordialmente ${ }^{18}$. Estos rasgos vienen en su mayor parte del Baltasar bíblico, al que la autora quiere «representante del despotismo de los reyes paganos, á par que de la corrupción é impotencia de una sociedad caduca» (Gómez de Avellaneda, 1869b: 298), mientras que el del hastío remite más a la creación romántica que encarna en el individuo escéptico y desengañado de la vida, también angustiado por no hallar nada en ella que llene el vacío.

En el drama, la caracterización de Baltasar ${ }^{19}$ se hace primero en ausencia del rey, en boca del profeta Daniel, como preámbulo a la exposición de la intriga que viene a desvelar a Joaquín y Rubén, en la que corre peligro la

${ }^{16}$ Cabe recordar que Dante, en el Infierno (Canto VII, vv. 120-126), ya incluía a los acidiosos:

Desde el limo exclamaban: «Triste hicimos
el aire dulce que del sol se alegra,
llevando dentro acidioso humo:
tristes estamos en el negro cieno.»
Se atraviesa este himno en su gaznate,
y enteras no les salen las palabras.

Laura, en La conjuración de Venecia, le habla a Ruggiero de «el vacío de tu corazón», para referirse a su infelicidad. Sebold, por su parte, demostró que 'fastidio universal' era la denominación con que Meléndez Valdés se refería a la angustia romántica. (1989, 157-169).

17 «...no es , sin embargo, en mi obra un personaje de repugnante odiosidad. He querido pintar en él lo poco que es la más grande alma cuando no la ilumina la fe ni la fecunda el amor»(Gómez de Avellaneda, 1869b: 298).

18 «Baltasar, el alma devorada por el hastío de la vida entre todos los goces materiales y todas las pompas de la vanidad mundana; el alma sin dios, que no se satisface con recibir de la tierra las adoraciones que ella le niega al cielo; el alma soberbia, que se imagina sin semejante entre los hombres» (Gómez de Avellaneda, 1858: 298).

${ }^{19}$ Un análisis riguroso de los rasgos básicos que caracterizan a este personajes y a los principales de la obra se da en Gutiérrez (1995). Capellán de la Cruz (1991: 479) destaca como el mayor mérito de la obra la creación de su personaje protagonista. 
virtud $^{20}$ de Elda. El profeta traza la semblanza del rey y situación en que se encuentra:

«De Nabucodonosor,

Aquel tirano opresor

De la triste humanidad,

Nació el déspota que al mundo

Postrado á sus plantas mira,

Y no lo huella con ira,

Mas sí con desden profundo.

No puso Dios en su seno

Un corazón bajo, no,

Y disfrutó sin placer.

Vió en sus dioses vanos nombres,

Sus caprichos en las leyes,

$\mathrm{Su}$ herencia en el mundo... iy greyes,

Viles greyes, en los hombres!

[...]

Saciado

De mando, grandeza y goces,

Ya con arrugas precoces

Se halla su rostro surcado;

$\mathrm{Y}$ en la edad bella y florida,

Mustia y enervada su alma,

Se postra -sin hallar calma

Por el tedio consumida.

Pero temprano agotó

De los vicios el veneno.

Desde la cuna, potente,

Dichoso desde la cuna

No encontró gloria ninguna

Que conquistarse valiente.

Todo lo tuvo al nacer;

De todo pudo abusar;

Poseyó sin desear

¡Tal es el rey Baltasar!

¡Tal la extraña situación

En que lo ve esta nación,

Que desdeña gobernar!

Aquel príncipe absoluto

Que manda en provincias tantas,

Y á cuyas soberbias plantas

Los reyes rinden tributo,

De su molicie el exceso,

Y por desprecio el poder,

En manos de una mujer

Del cetro depone el peso. (1869b: 316)

${ }^{20}$ Como bien nota Roldán (1994: 593-597), en ningún momento se nombra la palabra «virginidad». 
A continuación, ya en el segundo acto, será la reina la que aluda a su hijo con preocupación, por su endiosamiento y alejamiento orgulloso del afecto, como Nabuco, a pesar de que «ni su gloria le excuse,/ Ni sus triunfos le enaltezcan.»

La presentación personal de Baltasar, su actitud, sus palabras, corroboran la imagen dada de él y dan consistencia, vigor y atractivo al personaje; quedan bien de manifiesto su sombrío hastío, su escepticismo ante la existencia de algo que merezca la pena y su soberbia y vanidad: Baltasar ordena que cese el himno que lo alaba («iBasta!»Con cansancio) y, ante la insistencia de Neregel («iSiempre lo mismo!...»), accede a que siga la fiesta, pero desbarata con un puntapié las guirnaldas y ordena que se vayan las mujeres y arroje de allí esas flores: «¡Tanto incienso me sofoca!»(1869b: 327); Neregel se disculpa balbuciente y Todo turbado aduciendo que sólo quería con la fiesta «Luchar contra el hondo tedio/ Que solo te causa enojos...». El rey entonces pregunta si

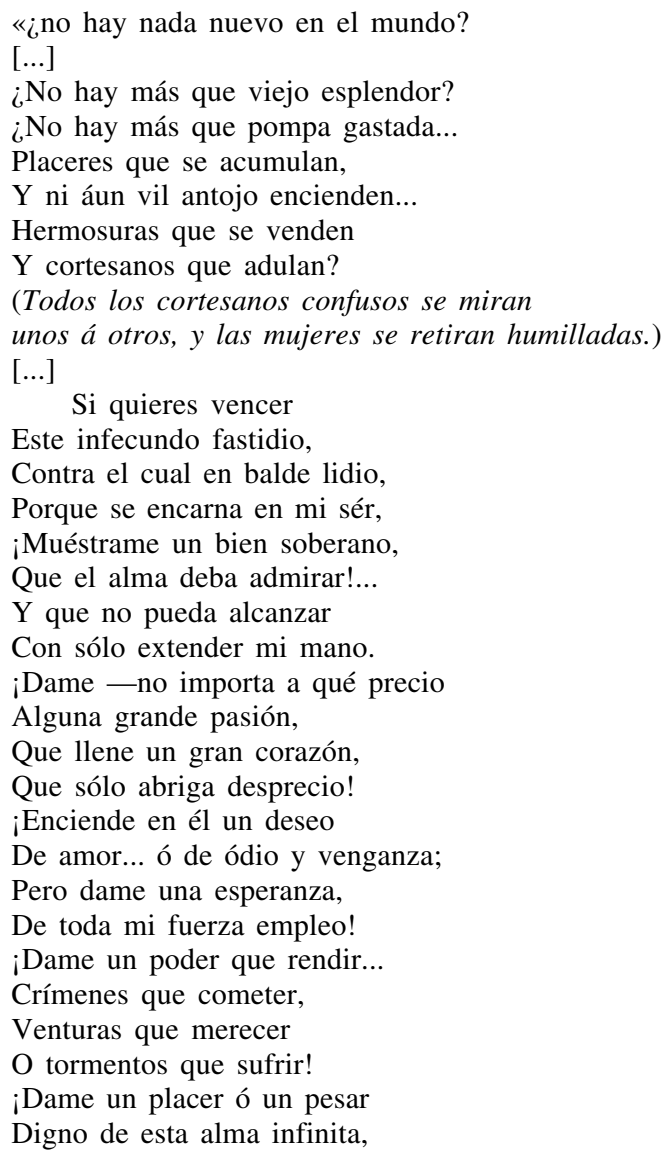




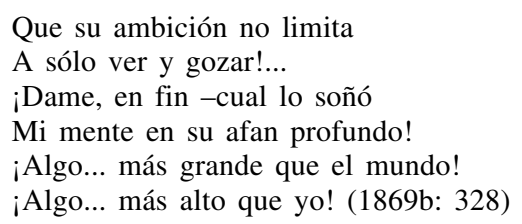

Rabsares y Neregel replican con humildad que eso es imposible, pero Nitocris le hace ver que debería gobernar, que esa responsabilidad llenaría «el vacío/ De esa alma grande y ardiente.» (1869b: 328).

Gómez de Avellaneda dispone entonces un debate entre Nitocris y Baltasar, defendiendo la primera la necesidad del gobernante y su obligación, mientras el rey, pesimista, considera que de nada sirve el buen gobernante, porque la especie humana lleva «desorden» y «vicio» en su seno; la reina, entonces, le replica que gobernando, sus antecesores se hicieron «armipotentes» y «eternizaron su nombre» (1869b: 329), a lo que el rey con sarcasmo amargo replica que «Los hizo dioses el mundo/ A par que polvo la muerte.» La reina quiere hacerle ver a su hijo que las glorias de sus antepasados son «inmortales», pero Baltasar rehúsa ganar gloria mediante la guerra («que brinde pasto a los cuervos/ por un palmo más de tierra / y un rebaño más de siervos.»). Nitocris, sin avance, le pregunta si no tiene deberes que cumplir y Baltasar responde con el pensamiento eje del drama: «iSí! devorar mi impotencia.» Y a la pregunta —ociosa hecha por la madre— de «¿qué mal sufres?», la respuesta es aplastante: «iLa existencia!». Opta, entonces, Nitocris por encarecerle el beneficio espiritual de favorecer a los que sufren, derramar beneficios, corresponder a los méritos, reconocer la virtud, alcanzar la gloria; pero Baltasar lo niega todo: envidia al que sufre ( «iSoy tan dichoso, señora,/ Que tengo envidia al dolor!», 1869b: 330), derramar beneficios se vuelve veneno cuando caen en seno indigno, sobran vicios, la virtud no alcanza a los humanos y la gloria es humo. Nitocris intenta hacerle ver que tal abandono puede deslustrar el trono heredado; pero Baltasar deplora, justamente, el no haber hecho nada para merecerlo ( ¡Gloria fuera el conquistarla [la altura en que se halla]; /Su posesión no es ventura!», 1869b: 330). Nitocris exhorta, entonces, a Baltasar a que recuerde al gran Nabucodonosor, pero tampoco el rey está dispuesto a ello, ya que «Se fue á olvidar entre fieras/ la gloria de regir hombres.» y termina impidiendo que su madre pueda seguir hablando ( Sólo decirte me resta...», dice ella, y él: «¡Nada más!» (Vuelve a sentarse y á caer en su apatía).

Y aún hay otra tercera semblanza del rey, que es la que le hace, cara a cara, Rubén, al enfrentarse a él para defender la virtud de Elda:

«No; ;te conozco bien! Sé que á tu frente

Ciñes una diadema que desdoras,

Y no sabrías defender valiente.

Sé que sin gloria, sin virtud, sin brío, 
Cansado de ti propio, entre perfumes
Tu inútil vida, cual mujer, consumes,
Mísera presa de infecundo hastío.
Sé que á la ley de tu capricho loco
Viendo postrado un pueblo envilecido,
La inmensa humanidad tienes en poco,
Y hasta por Dios blasfemas descreído.
¡Mas por él, Baltasar, reinan los reyes,
Que deben ser su imágen; y es en vano
Pida respeto al mundo el vil tirano
Que impera sólo sobre indignas greyes!» (1869b:338)

A este personaje, así establecido, Gómez de Avellaneda no enfrenta al profeta Daniel, sino que, cambiando la pauta bíblica, inventa dos personajes, Elda y Rubén, la mujer y el esclavo, para que sirvan de piedra de toque al monarca. Tal como lo entiende la autora: «Elda y Rubén representan en este pequeño cuadro los dos seres más débiles y abyectos de la sociedad antigua: la mujer y el esclavo, rehabilitados sólo por el Cristianismo.» (1869b: 298). Dejando de lado que, siendo mujer y esclavo, siguen perteneciendo a la nobleza hebrea, lo que sí cabe notar es que se trata de personajes de menor novedad y atractivo, que se resienten del tópico y de haber sido concebidos para servir de piedra de toque a Baltasar. Se trata de dos personajes que cumplen una misma función.

Tiene clara también la autora la andadura de su drama, en cuanto al efecto que debe surtir el contacto, el choque más bien, de Baltasar con Elda y Rubén $^{21}$. Elda - el incuestionable sujeto actancial del drama, el verdadero motor de las acciones que en él se desarrollan»(Gutiérrez, 1995: 207)— está conformada sobre el tópico de la muchacha bella, virtuosa, tierna, humilde y abnegada, un «Ángel ${ }^{22}$ de santa piedad», para el rey el cautivo, como le dice

\footnotetext{
${ }^{21}$ «En aquellos dos seres encuentra, sin embargo, el déspota oriental el límite invencible de su poder tiránico. Baltasar, el alma devorada por el hastío de la vida entre todos los goces materiales y todas las pompas de la vanidad mundana; el alma sin dios, que no se satisface con recibir de la tierra las adoraciones que ella le niega al cielo; el alma soberbia, que se imagina sin semejante entre los hombres, encuentra en la mujer y en el siervo la primera revelación de la dignidad humana y de la pequeñez de las potestades terrestres. El cetro del dios mortal de Babilonia se estrella en la virtud de dos corazones fieles, y en balde les pide el amor y la felicidad, del que se halla desheredado en la cumbre solitaria de su grandeza egoísta. Ciego Baltasar con la impotencia de su primer deseo, venga su desventura de hombre con su tiranía de déspota; huella la virtud que ha negado en su escepticismo, y que encuentra y reconoce para su castigo. La virtud, negándole la dicha, le deja el remordimiento: comprende en la desesperación de su soledad que existen para el alma goces purísimos, que Dios no rehusa á las más bajas condiciones sociales, pero sí al soberbio que desconoce á sus semejantes en la tierra y á su infalible Juez en el cielo. Siente, en fin, el vacío inmenso de un alma sin fe ni amor, y quiere ahogar en vano entre los vapores de la orgía el grito de aquel dolor profundo, expiación providencial del orgullo.» (1869b: 298).

${ }^{22}$ «Ángel» (no mera mujer), como nomina Rugiero a Laura, en La conjuración de Venecia y Álvaro a Leonor, en Don Álvaro o La fuerza del sino.
} 
Joaquín (1869b: 304) ${ }^{23}$. Es sobrina de Daniel, ha sido adoptada como hija por el rey y será hija por matrimonio con Rubén, nieto del rey de los judíos. En su aparición ante Baltasar pasará a encarnar la figura de la mujer fuerte de la Biblia (Laguerre, 1981) y, una vez muerto Rubén, pasará a desempeñar el papel de la mujer enajenada por el dolor y el amor, una muestra más de las delirantes de la literatura romántica (Ribao Pereira, 1999) ${ }^{24}$. En el drama romántico, el papel de la heroína es el de proporcionar al héroe angustiado un lenitivo para la angustia que se origina en el vacío dejado por la ausencia de Dios. En Baltasar se ejemplifica muy bien (quizá mejor que en ningún otro drama o tragedia romántica esa ausencia de Dios y hasta de pensamiento religioso alguno, bien que para derrotar esta postura ${ }^{25}$ ) y, sin embargo, el patrón religioso desvía la función de Elda: no puede ser (como Mirra en Sardanápalo) la dadora del amor a Baltasar, puesto que su compromiso religioso, político y humano la alejan del rey; así, despierta en Baltasar esa posibilidad afectiva, pero la cierra de inmediato, sumiéndolo en una acedía más profunda que aquella en que estaba antes de conocerla. De manera distinta a otros dramas románticos, Elda vendría a subrayar el sentimiento de vacío existencial; es la mujer de belleza (y virtud) fatal que despierta en el hombre el ansia de infinito, el deseo de lo sublime, la razón de ser de la vida, pero que luego se le arrebata al héroe, dejándolo (con expresión repetida), al borde del abismo.

Rubén es descrito, como Baltasar, en ausencia, en torno a dos motivos, el del matrimonio y el de la rebelión: «En tu nieto generoso/ no impera sólo el amor; Que aunque nacido en destierro/ Y bajo el yugo de hierro/ Del más indigno opresor,/ No en balde sangre real/ Siente correr por sus venas.../¡Al compás de las cadenas/ No alzará el himno triunfal!/ Aguardemos; confianza tengo en la augusta promesa.» (1869b: 304). Cuando aparece en escena - y hasta que acabe su papel— se mostrará como un muchacho vehemente en sus sentimientos amorosos y políticos: emocionándose dolorido, al saber que Elda va a abandonar la prisión para pasar al séquito de Nitocris, y reprochándole «con impetuosidad» el no haber rechazado la propuesta de la reina, haciéndole saber que esa mazmorra había sido su único hogar durante

${ }^{23} \mathrm{Y}$ muy parecida en estos rasgos a la Mirra byroniana (y a tantas heroínas románticas construidas con este patrón) sentimental.

${ }^{24}$ La crítica ha abundado en la defensa de sus ideales feministas que lleva a cabo Gertrudis Gómez de Avellaneda a partir de las figuras femeninas de su teatro o de sus novelas (Laguerre, 1981; Cantero García, 2003); sin embargo, a la vista de estas facetas tan distintas entre sí no me queda claro — al menos a primera vista- qué imagen de mujer es la que pretende ofrecer la autora; más bien, parece que se opta por la amalgama de cualidades y valores y, sobre todo, por dotarla de protagonismo y actividad.

${ }_{25}$ Amalia Roldán (1994: 596) concluye su artículo afirmando que «La fuerza de la estructura del drama reside en las relaciones entre el mundo pagano y el mundo cristiano confiadas al un personaje femenino Elda.» 
toda su vida ${ }^{26}$, aunque aceptando de inmediato el razonamiento de la muchacha, cuando le aduce que hubiera sido muy arriesgado rechazar el favor de la reina (que también incluía la próxima libertad del «ciego»), causando quizá su odio; animándola a aceptar, conmovido, no sordo al grito del deber, siempre fiado en que la Providencia ponga fin a sus pesares. El personaje está siempre recorrido por una energía violenta, así correrá angustiado a defender la virtud de Elda, tras el aviso de Daniel, al que intentará matar y al que asombrará y conmoverá, al desafiar la muerte con valor. Su volcanismo lo hace siempre extremo, lo mismo para manifestarle a Elda su sospecha y su temor de que haya sido deshonrada por Baltasar, como para pedirle perdón de inmediato, con el mismo fuego; rasgando el edicto del rey en que lo nombraba el segundo en su reino y el primero de su corte, y exasperándolo con sus invectivas, hasta ser entregado por Baltasar al odio homicida del populacho cuando conoce que Elda es su esposa ante Dios.

La autora, como vengo diciendo, concibió a estos dos personajes como los elementos de una misma función, la de servir de revulsivo a la conciencia acorchada de Baltasar. En principio, lo esperable sería que la muchacha lo hiciera en el terreno sentimental-erótico ${ }^{27}$, mientras Rubén lo hiciera en el político. Pero Gómez de Avellaneda dota a Elda del valor de las mujeres fuertes de la Biblia, como Judith o Esther y así hace que la comunidad de los dos personajes se sustancie en torno al amor, la religión y la patria, los tres componentes del voto que hace Elda y que corrobora Rubén ante el rey que los casa en nombre de Dios. Cuando Joaquín aconseja a Elda que no olvide en su nueva situación la esclavitud de Sión y que sea siempre fiel a su pueblo y a su Dios, la muchacha jura serlo, arrodillada y «con solemnidad» pronuncia «Juro conservarme fiel/ A Dios, mi patria y mi amor!», a lo que responde el muchacho «Arrodillándose también» aceptando los votos de la muchacha y dándole su mano ante su padre y el cielo, siendo casados ambos por el anciano rey. (1869b: 313).

En el comienzo del drama Elda pulsa, sobre todo, el resorte sentimental, tanto con Joaquín como con Rubén; al emotivo parlamento de éste sobre la

26

$$
\begin{aligned}
& \text { «Y aquí! -la hubiese dicho- jaquí he pasado } \\
& \text { Todos mis goces, todos mis dolores! } \\
& \text { En el recinto de tan triste estancia } \\
& \text { Mi juventud se alberga desvalida, } \\
& \text { Y aquí mi amante y yo desde la infancia } \\
& \text { Vivimos juntos de una misma vida; } \\
& \text { Bien como dos arbustos infelices } \\
& \text { Que bajo extraño sol lánguidos crecen, } \\
& \text { Y entrelazando ramas y raíces, } \\
& \text { Arrimo mutuo y fraternal se ofrecen.» (1869b: 309) }
\end{aligned}
$$

${ }^{27}$ Mata Induráin (1998: 207) considera que «la pasión que comienza a sentir el rey, subyugado por el indómito carácter de Elda, hace peligrar la relación de la joven con Rubén». Se ha de entender que no por duda o debilidad de la muchacha, sino por el sentido agudo del honor de su marido. 
cárcel como el hogar, Elda responde con un nuevo parlamento, acertado en lo sentimental, invocando los «recuerdos tiernos/ que estimar debe el triste que los deja» y va haciendo un repaso cargado de sentimiento que conmueve vivamente a Rubén («Vivamente conmovido «¡No más!») y ha de causar similar efecto en el público, y que termina con este colofón:

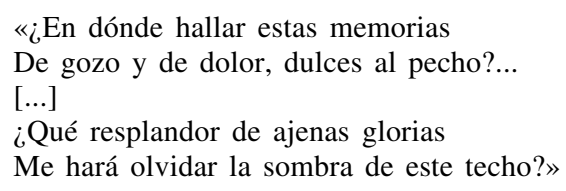

Sin embargo, en su relación con Baltasar serán las facetas religiosa y política de Elda las que predominen. Así, la siguiente aparición de Elda ya será en palacio, ante Baltasar, negándose con dignidad altiva a tocar y cantar para el tirano y haciéndose portavoz del ideario religioso y político de su pueblo, en un alegato vibrante:

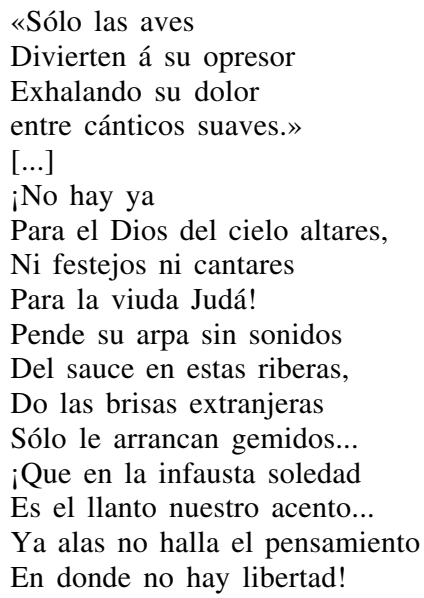

(1869b: 231)

Elda llega a replicar al rey que los judíos ven en él al vencedor, pero no a su rey y cuando Neregel le coloca el salterio en las manos para que cante, ella lo arroja al suelo diciendo «No hay en el mundo cadenas/ Que rindan la voluntad.» (1869b: 332), lo que completa con «Las gentes de mi creencia/ Solo de Dios á presencia/ Deben doblar la rodilla.», y no tiene inconveniente en seguir insolentándose ante el rey, cuando le pregunta qué delito ha cometido el padre de la muchacha para que esta le responda diciendo: «El defender su corona/ Que el tuyo abatió tirano.», hasta que, con asombro de todos por la «audacia» de la muchacha, Baltasar ordena que liberen a Joaquín y le asignen una renta digna de su condición. 
Convertido Baltasar en protagonista del drama y enfrentados a él Elda y Rubén, el lugar del profeta Daniel y su función se ven desplazados, con respecto al guión de la Biblia. Tomada esta decisión, el peligro para la obra estaba en que la personificación del profeta en las tablas no diera la talla sobrehumana que tiene en la Biblia y, sabedora de ello, la autora se aplica a conjurarlo.

Como en el caso de Baltasar, Daniel ha sido presentado en ausencia por la reina, pero en este caso no hay novedad sobre los rasgos con que lo define la Biblia: se trata de un hombre de fe, sabio, tan respetable y prestigioso como para que la reina favorezca por su valía al pueblo judío ${ }^{28}$. A continuación, aparece el mismo Daniel en escena, con una salutación al rey cargada de valor religioso-político y un relato sobre la intriga que puede empañar la virtud de Elda que incluye la semblanza de Baltasar; ahora bien, tal embajada podría haberla hecho cualquier personaje de talla humana, lo que atenta contra el halo que debe desprender la figura del profeta; la solución que halla la autora es la de «teatralizarlo», reservándole el final del primer acto, cargado de patetismo por la inquietud que sienten por la suerte que pueda correr Elda, con una intervención muy teatral, que prefigura la que cerrará la obra:

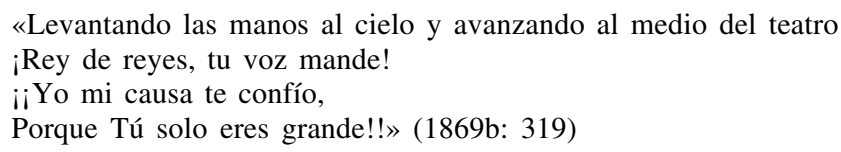

No vuelve a aparecer Daniel hasta el último acto de la obra, para formar parte del desfile de voces admonitorias que se alzan hacia Baltasar, en este caso - como se ha dicho- con una lectura providencialista de la historia que profetiza la caída del rey y de su imperio y la libertad de los hebreos, lo que le gana la orden de prisión por parte de Baltasar, lugar en el que parará poco porque de inmediato se produce el prodigio de la mano que escribe y los magos y sátrapas babilónicos expresan con exclamaciones su terror y confusión; Baltasar exige que le revelen el significado del prodigio pero todos sus adivinos se declaran impotentes. Nitocris, entonces, le recuerda que Daniel ya fue famoso por interpretar los sueños de Nabucodonosor y que su voz fue acento de la verdad divina; al oír la palabra verdad, Baltasar se estremece, pero promete colmar al profeta de honores y riquezas. La autora es consciente de que la llegada de Daniel en esta ocasión sí que debe tener un relieve especial y, junto a la trascendencia de la situación (proyectada sobre el fondo histórico conocido por los espectadores), dispone a dos personajes transmisores del sentimiento hacia los espectadores: Baltasar, que dice sentir espanto a su pesar y Joaquín que dice sentir el alma estremecida de emoción. Daniel inter-

\footnotetext{
${ }^{28}$ Así, cuando Nitocris informa a Joaquín de que quiere «templar» el «infortunio» del cautivo y obtener su liberación, como preludio a la del pueblo judío, la razón que aduce es que «De Daniel, tu noble tío (A Elda)/ en mucho aprecio el saber» (1869b: 305).
} 
preta el prodigio, con un parlamento breve que se resiente de ser repetitivo con respecto al que pronunciara momentos antes y sale, tras rechazar el manto real que le ofrece Baltasar en pago a su interpretación. Pero Gómez de Avellaneda, consciente de que el personaje bíblico ha de tener mayor relieve aún $\mathrm{y}$, sobre todo, transmitir la emoción de lo sobrenatural, le reserva una última intervención, estelar, en la que su figura se agranda, al profetizar - como se ha dicho- no sólo la reconstrucción del templo de Salomón, sino la venida del Mesías. La autora está muy pendiente de suscitar la emoción debida y, a la trascendencia de las palabras del profeta, cuida de unir los elementos paraverbales adecuados («con voz solemne y avanzando hácia el medio de la escena [...] Con inspiración») y la acción del personaje amplificador y transmisor de la emoción que, nuevamente, vuelve a ser el rey Joaquín, quien, «cayendo de rodillas y juntando las manos con transporte», sólo alcanza a exclamar un expresivo «iiAh!!...» (1869b:389).

El rey judío Joaquín de este drama, aun respondiendo a la realidad histórica, es otra licencia de la autora sobre el texto bíblico, ya que no aparece en el Libro de Daniel ni, por supuesto, relacionado con Baltasar. Gómez de Avellaneda le ha adjudicado en su obra la función de movilizar la compasión del espectador, desde el patetismo que su figura, (cautivo, anciano y ciego), palabras y hechos provocan.

Con él se abre el drama, tanto para mostrar la situación del pueblo hebreo a través de la de su rey, como para establecer el término de la contraposición a Baltasar: el rey del pueblo hebreo, en efecto, está adornado por hermosas virtudes: el convencimiento en lo pasajero de las glorias del mundo («iHuyó cual humo mi gloria», 1869b: 303), la confianza en Dios, la esperanza en su misericordia y perdón y el cariño agradecido que siente por Elda y Rubén.

Joaquín va a ser el personaje amplificador de cuanta situación patética presente la obra. El final del segundo acto, por ejemplo, presenta a un Rubén, avergonzado por no haber sido capaz de matar a Baltasar, que, rehúsa darse muerte. El patetismo del hombre y del esposo derrotados se lleva a la exasperación cuando llega Joaquín, desconocedor de la suerte de Elda, que llega a sospechar, por el silencio y el temblor de la mano del muchacho, para gritar que va a arrodillar sus canas ante el tirano para que le devuelva a su hija y «con trágica transición» afirma que, si no le escucha, ciego y todo tomaría la espada para matar al tirano, suplicándole a Dios la vista; Gómez de Avellaneda vuelve a cuidar la conjunción de la palabra, el gesto y el movimiento y dispone que «Se llev[e] la mano a los ojos, como queriendo arrancar el velo sempiterno que los cubre, y [diga] luego con voz sombría»: «¡Nunca!... ¡Noche profunda! ¡Noche horrenda!» (1869b: 342) y que, aun así, persevere angustiosamente buscando la «salida con pasos vacilantes, y extendidas sus trémulas manos», hasta que Daniel lo detiene advirtiéndole que «isólo á Dios le toca la venganza!» (1869b: 342). Vuelve Joaquín a cumplir esta función en el final del tercer acto, también de gran patetismo, ante la muerte inminente 
de Rubén, con las exclamaciones de dolor de Joaquín y Elda, el desmayo de ésta, la orden de Neregel de que «iDestrocen/ Vuestras manos á ese infame,/ Y que á la plaza se arrojen/ sus restos sangrientos!» (1869b: 362), las voces del populacho, que se ha posesionado de la víctima, y la arrastra al vestíbu$l o$, gritando «¡Muera!», Rubén que llama a su padre y éste que cae desfallecido en medio de la escena, mientras aparece la reina y corre en defensa de la víctima gritando «¡Dioses!» (íd.). Y, ya en el desenlace del drama, tras mostrar espanto por el brindis sacrílego de Baltasar, y pedir a Dios piedad para un Baltasar moribundo, queda para aconsejar al profeta que se ponga a salvo de Ciro y para dar cuerpo y voz al efecto que ha de provocar la profecía final de Daniel, cayendo de rodillas y juntando las manos con trasporte.

Entre estos dos mundos claramente enfrentados, el babilónico y el hebreo, Gómez de Avellaneda ha tendido una pasarela mediante la madre del rey, Nitocris, gobernante justa y bondadosa, que vendría a responder a la práctica histórica de los usos de Nabucodonosor, que, al deportar a las familias más significadas de Judá, acogió a algunos de sus miembros entre su corte; ello, sin dejar de lado el interés de la autora por configurar un personaje femenino digno y muy atractivo. Este personaje femenino está configurado con cuidado, más para cumplir el papel de consejera honesta y sabia, que para el de reina regente ${ }^{29}$. En efecto, parte del papel que la Biblia asigna a Daniel, como consejero de Nabucodonosor y Ciro, pasa en este drama al cuidado de la madre del rey. Pero la condición de reina es también importante, porque es la que sustenta el descontento de los ambiciosos Rabsares y Neregel que, además, no pueden soportar que sea una mujer la que ostente y detente el gobierno, con lo que se da razón para la intriga que moviliza la obra, tal como lo indica Daniel, al relatar la situación de Baltasar y su reino ${ }^{30}$. Pero, en realidad, su función es la de aconsejar a su hijo Baltasar sobre las condiciones de un buen gobernante, al tiempo que aboga por la indulgencia hacia los hebreos, a cuyos representantes, Daniel, Joaquín, Elda y Rubén, sabe respetar y apreciar. Si su presentación la muestra como bondadosa ante la suerte de los judíos, su sensatez y perspicacia políticas quedan de manifiesto en la lectura que hace a Rabsares sobre la precaria fidelidad o sujeción de los reinos vasallos ${ }^{31}$ y las

${ }^{29}$ Aunque se refiera que a su decisión se debe la canalización del Eúfrates y el aprovechamiento de las tierras desecadas para la agricultura, que le alaba el adulador Rabsares y que al final de la obra le reprochará como causa del acceso franco que los persas y medos han encontrado para entrar en Babilonia.

30 «Y por desprecio al poder/ En manos de una mujer/ Del cetro depone el peso./ [su madre] Que es generosa/ Y de su imperio no abusa;/ Aunque de hacerlo la acusa/ Toda la corte celosa./ Son por su influjo ofendidos/ Los que ejercerlo ambicionan,/ Y su virtud no perdonan/ Los sátrapas corrompidos.» (1869b: 317).

${ }^{31}$ Rabsares considera que todos los pueblos vasallos seguirán amedrentados por las lecciones «harto sangrientas» que los asirios les infligieron. Nitocris hace otra lectura, con dos argumentos: los pueblos hollados forman parte del imperio asirio, están dentro, y circula «la venganza/ Sorda y profunda en sus venas.»(1869b: 323). 
distintas formas de gobierno ${ }^{32}$, mientras su figura se robustece en el debate que sostiene con Baltasar, en el que aconseja y recrimina al monarca por su irresponsabilidad, encareciéndole la necesidad del gobernante y sus obligaciones, la importancia del poderío militar y la trascendencia de la fama, y, cuando ve cómo estos valores se estrellan contra el hastío escéptico del rey (que replica aludiendo a la maldad de la naturaleza humana, el valor de las conquistas y la nada a que reduce a todos la muerte), aún opta por encarecerle el beneficio espiritual de favorecer a los que sufren, derramar beneficios, corresponder a los méritos y reconocer la virtud, con igual resultado; su última apreciación atiende a intentar hacer ver al rey que tal abandono del gobierno puede deslustrar el trono heredado con gloria de Nabuco, sin que consiga más que la orden del rey de que calle.

Tras este debate de altura, central en el drama y eficaz no sólo para poner de manifiesto el pensamiento de la autora sobre el buen gobernante, sino para caracterizar a Baltasar, Nitocris es retirada discretamente de la obra por Gómez de Avellaneda en el momento cumbre en que Baltasar ordena la muerte cruel de Rubén y vuelve a despeñarse en el escepticismo. La presencia de la reina en ese momento hubiera supuesto para la autora un conflicto grave: por un lado, se trataba de elevar a la dignidad de segundo en su reino a Rubén, por encima de la reina misma, por otro, la segura intercesión de Nitocris a favor de los judíos, hubiera exigido un desaire notorio por parte del rey hacia su madre y un más que posible desarrollo distinto de la trama. Así, Nitocris vuelve a aparecer al comienzo del cuarto acto para devolver a su hijo el sello real y renunciar a ejercer el poder, porque no sirvió para detener la violencia homicida del populacho contra Rubén, lamentándose por no haber visto cumplida su esperanza de que su hijo saliera de su letargo para alcanzar la gloria, dando ventura a sus pueblos como un monarca justo. La réplica de Baltasar es similar a la del anterior debate, como lo siguen siendo también los argumentos de Nitocris, aunque los parlamentos de ambos están empapados ahora del dolor de la derrota de las ilusiones. A lo largo del banquete, mientras el rey, sus dignatarios y los sátrapas se dedican a la orgía, la autora la presenta preocupada por la situación política, hablando con los sátrapas sobre el estado de sus gobiernos, recibiendo de ellos mentiras descaradas, mientras en apartes van expresando sus deseos de que caiga la reina. La apoteosis del dolor de este personaje femenino comienza cuando Rabsares la culpa de imprevisión, por haber dado la idea a Ciro de desviar el cauce del río, encontrando así paso franco a la ciudad. A partir de aquí, Nitocris se vuelca en el papel de madre, transida de dolor, que teme por la vida de su hijo en la batalla, con ruegos a Baltasar para que huya y a Daniel y Joaquín para que su dios

${ }^{32}$ Mientras Nabuco prefirió ser adorado como un dios por sus súbditos, en vez de ser querido, algo en que lo imitó Baltasar («Baltasar su orgullo hereda.», pero, «Sin que su gloria le excuse,/ $\mathrm{Ni}$ sus triunfos le enaltezcan.»). (id.). 
acepte la ofrenda de su propia vida por la de su hijo y acogiendo, al fin el cadáver de Baltasar. Pero esta condición maternal no borra la de la reina, consciente de su dignidad; bien al contrario, Gómez de Avellaneda — con recurso que remite más a la tragedia que al drama- dispone que Nitocris incendie el palacio real para evitar que los invasores huellen los despojos de su hijo y no tener que contemplar el baldón del cetro asirio. De hecho, el final del drama lo reserva la autora al gesto de tremendo patetismo de la madre y reina dispuesta a perecer abrazada al cadáver del hijo en la pira funeraria del palacio en llamas.

\section{DESARROLLO DE LA OBRA: ATEÍSMO Y HASTÍO VITAL FRENTE A LA RELIGIÓN}

Así configurados los personajes principales del conflicto y dispuesto su planteamiento, el desarrollo posterior del drama se traza con una cierta previsibilidad y, a veces, con elementos no de la mejor calidad dramática, aunque ello no vaya en detrimento de la consecución de algunas situaciones vigorosas, de parlamentos muy logrados y de la configuración de un Baltasar sugerente y atractivo ${ }^{33}$.

En efecto, Baltasar no tarda en sentir cómo revive su corazón por la valentía de Elda y Rubén y se enamora de la muchacha, a la que cree hermana de Rubén, sin que nadie en la corte lo saque del error funesto (valga el adjetivo tan romántico), ni su madre (que ha querido que Elda pasase a formar parte de su séquito y conoce bien a los judíos cautivos), ni, por supuesto, Rabsares y Neregel (otros dos personajes que cumplen una misma función), urdidores de la intriga política que permitirá llevar el drama hasta la caída del rey y de Babilonia. Baltasar se presenta al comienzo del tercer acto transportado por «un placer inefable», al contemplar que puede amar y que espera ser amado, por haberse convertido en un hombre dejando de ser meramente un rey. («ץYo soy hombre! ¡Yo deseo!», 1869b: 349); en tal estado es inconmovible por las noticias de la ofensiva de los persas y los medos y, por el contrario, proclive a favorecer todo aquello que tenga que ver con los judíos, como acoger al dios de los cautivos junto a los propios de Babilonia, liberar a Joaquín y elevar a Rubén a la dignidad de segundo de su reino y primero de su corte, afrontando con altivez a su pueblo soliviantado.

La que habría de ser la escena de amor de Baltasar hacia Elda (III, $4^{\mathrm{a}}$ ) es desviada pronto por la muchacha hacia otros asuntos, antes aún de que el rey haya podido hablar de su pasión por ella: Elda viene a pedir protección para

\footnotetext{
${ }^{33}$ Narciso Alonso Cortés, admirador de la obra, ensalza su forma: «Pero lo principal en este drama [...] es la jugosidad de la forma, bien alejada de la rigidez usual en la tragedia clasicista, y la naturalidad, llena de poesía, con que los hechos se eslabonan y desarrollan. En todo hay frescura y movimiento: en la acción, en el estilo, y, por descontado, en la versificación, superior a la de casi todos los dramáticos de la época.» (1968: 286).
} 
su pueblo, porque ha visto excitada a la plebe contra los judíos y Baltasar la calma jurándole que los protegerá, por «el gran bien que me has hecho» (1869b: 353), librándolo del hastío (aunque no lo nombra así):

«Toca este pecho,

Que en un ambiente más puro

Ya comienza a respirar,

Y que de la muerte el frío

Guardaba en su hondo vacío,

Cansado de despreciar.

Dime si tu pecho alcanza

Lo que es el mal inclemente

Que luz le niega a la mente

Y al corazón esperanza...

Que sofoca el sentimiento

Y los sentidos embarga...

Que hace la vida una carga

$\mathrm{Y}$ un azote el pensamiento.»

(1869b: 353)

Elda se nombra esclava y Baltasar rechaza el nombre: « Dame un alma libre, ardiente!.../ No me hables de esclavitud.» (1869b: 354). Elda (como antes Nitocris, pero por esquivar que el rey hable de amor), intenta convencer al rey de la conveniencia de que reine con justicia y busque el afecto de sus súbditos $\mathrm{y}$ «Si el mando te causa hastío,/ Si no hay placer que te cuadre,/ Sé de cien pueblos el padre,/ Y de tu pecho el vacío/ Llenará su amor inmenso!» (íd.). Baltasar se debate ante la extrañeza de estas propuestas, pero concede que han de ser buenas, viniendo de Elda, a la que debe el «cambio apetecido» que ha experimentado. Elda sigue encareciendo la virtud y animando a ella al rey. Pero no habrá tal escena de amor, ni siquiera se permitirá a Baltasar expresar su amor, decir su pasión y los matices de su sentimiento, como ocurre con otros héroes románticos. Gómez de Avellaneda trazó para este rey un camino fulgurante de ascenso en la ilusión y caída en la desesperación.

Cabe preguntarse por qué Gómez de Avellaneda lo dispuso así: no parece que fuera por temor a no saber imprimir a las palabras del rey el calor apropiado, ya que otros muchos parlamentos de la obra la revelan como una autora capaz en el registro sentimental y patético. Debió de ser porque sólo le interesaba el personaje en cuanto a ejemplificador de lo poco que es el hombre ante los designios de Dios, el pagano ante la verdadera religión. De cualquier forma, el drama deja la impresión al espectador de habérsele hurtado un momento esperable y necesario. Quizá no se lo podía permitir, dado el engaño (lindante con la inverosimilitud), sobre el que está fundada la relación entre Elda y Baltasar. Las palabras de amor del rey no podrían sino obligar a la muchacha a envilecerse en el silencio o a revelar la verdad; si esto se producía estando ella y Baltasar a solas, obligaba a la autora a conseguir un patetismo en la intimidad, bien alejado de la espectacularidad de la situación que 
se consigue al revelarse la verdad en público y en el momento en que Baltasar favorece a los judíos y anuncia su deseo de desposar a Elda y hacerla reina. El final del tercer acto arrolla en el tumulto los puntos débiles de su construcción: Baltasar expresa su intención de que el pueblo adore a Elda, como su regia esposa, a lo que Rubén replica rasgando el edicto del rey, entendiéndolo como pago por los favores de su esposa: Baltasar se queda atónito ante la revelación; Joaquín hace tambalearse un tanto el eje de la verosimilitud de la obra al decir «iSeñor! no pienso que ignores/ Que tiene esposo»; Rubén le pide que no se la arrebate, que es lo único que tiene. Baltasar Inmóvil y con voz sorda se dice «№ son hermanos!» (1869b: 360); Elda explica el porqué de su engaño: «Se opusieron mis temores/ Á que esa verdad, señor, Te confesára. Perdone/ Tu compasión mi flaqueza./ ¡Mi llanto á tus plantas corre!». Los tres, de rodillas, le piden clemencia, mientras Baltasar sigue atónito y ensimismado: «¡No son hermanos!... ¡mentían!/ ¡Y yo encontrar pechos nobles/ pensé iluso!... ¡La verdad/ Yo quise hallar en los hombres!» (Suelta una carcajada convulsiva) (1869b: 361) y ordena que los guardias lleven a prisión a Elda, «sierva vil», como venganza ( $Y$ Y me vengue tu vergüenza/ De mis locas ilusiones!»). Baltasar entrega a Rubén a la ira del populacho, a cuyas manos perece, con el horror de Joaquín y Elda.

El cuarto acto se desarrolla en torno al banquete dispuesto por Baltasar para satisfacer a los sátrapas y tratar de mitigar su desengaño ( «iQuizás me conforte el alma (Con ironía acerba.)/ La crápula del festín!»; 1869b: 366). A la reconvención de la reina por su actuación, Baltasar replica con una amarga declaración de pesimista desilusión y escepticismo radical, negando la existencia de la dicha y afirmando Con desaliento doloroso la única realidad del dolor, traicionada su esperanza «traidora» (1869b: 364), como «humo leve», «ilusión de un sueño breve» (íd.).

$$
\begin{aligned}
& \text { «iVolóse!... Volví a caer } \\
& \text { En esta tierra maldita, } \\
& \text { Donde todo se marchita, } \\
& \text { Donde es sarcasmo el placer. } \\
& \text { Torno á escuchar ese acento } \\
& \text { Que la esperanza prohíbe... } \\
& \text { Y que mi oído percibe } \\
& \text { En cada soplo del viento } \\
& \text { ¡Ese acento que aquí gira, } \\
& \text { Que en todas partes murmura } \\
& \text { “No hay amor, verdad, ventura, } \\
& \text { Todo es miseria y mentira!”» }
\end{aligned}
$$

(1869b: 365)

y su decisión de que sus súbditos sientan el peso del mismo dolor que lo devora. No logrará sacarlo de esta actitud tampoco la disputa dialéctica que tiene con Daniel, quien se adelanta al prodigio de la mano que escribe en el muro, queriendo hacer ver al rey impío cómo hasta los males que afligen al 
ser humano son señales enviadas por Dios y, en particular, a los soberanos injustos:

Que en su balanza suprema

Son pesados los delitos

Y virtudes de los reinos...

Que si rompe el equilibrio

el mal al fin, si se borra

De honor el postrer vestigio,

$\mathrm{Y}$ caducando un imperio

Devorado por sus vicios,

La tierra llega á infectar

Con su aliento corrompido

¡Entonces Dios lo renueva

Por horrendos cataclismos,

Que á las viejas sociedades

Sepultan en hondo abismo!

(1869b: 370)

Y sigue adelantándose al prodigio, cuando Baltasar se burla preguntándole dónde estaba su Dios cuando los asirios conquistaron Judea y abatieron su templo, y Daniel admite que Dios los castigó por sus culpas, y profetiza: «Pero ese pueblo humillado/ Romperá pronto sus grillos!» (1869b: 371); anuncia después que Babilonia caerá bajo la espada de Ciro y que no puede, ni podrá ningún monarca, aniquilar al pueblo hebreo porque así está predicho.

En este desfile de figuras y adversarios dialécticos dispuesto por la autora para mostrar el estado en que se encuentra Baltasar y llevar el drama hacia la catástrofe, es Elda, perdida la razón, la que aporta la visión del palacio como un vasto cementerio, anticipando la victoria de Ciro, como expresa la autora:

«intuición misteriosa de la grande y próxima catástrofe. En medio de aquella pompa régia, de aquella delirante alegría, el monarca ateo, condenado por el cielo, va á hundirse para siempre con su imperio, con la corrompida sociedad que representa; y Elda, su víctima, anuncia ya, aunque con la exaltación de la demencia, aquel gran suceso providencial, sintiendo - por decirlo así- el olor de la muerte entre los perfumes del festín.» (1869b: 378)

Sólo queda Joaquín para terminar este desfile y será él precisamente el que, al contradecir al rey, brindando para negar la descreencia y el pesimismo de Baltasar, lleva a éste a que exija los vasos sagrados del templo de Salomón, para hacer el brindis oportuno, muy en la tradición romántica de la impiedad donjuanesca:

«iBien! Que ostente su gloria

Ese gran Dios de Jacob,

Y para brindar por él,

Haciéndole digno honor... 
¡Vengan los vasos sagrados

Del templo de Salomón!» (1869b: 382)

Y, ante el espanto de Joaquín, brinda:

« Por el Rey de reyes,

Ante el cual citado estoy!»

La progresión de los enfrentamientos y, sobre todo, este último hecho, propicia el efecto teatral, espectacular, de la aparición del prodigio narrado por la Biblia, interpretado ahora sí por Daniel, con una evidente redundancia respecto a su anterior parlamento:

\author{
«Pesó Dios tu justicia... hallóla falta, \\ Y el término marcó de tu carrera. \\ ¡Esa corona, que tu orgullo exalta, \\ Te la viene á arrancar mano extranjera! \\ ¡Entre Persas y Medos destrozada \\ Queda desde hoy tu inmensa monarquía, \\ Que — de siglos de crímenes cargada \\ Su sangriento poder al cabo expía!» (1869: 384)
}

Y sin transición, se anuncia del ataque imparable del ejército de Ciro, leído como venganza divina por Daniel y Joaquín (“¡Cuál vengas, Señor, tu gloria!”, 386), que permite desenlazar la obra con patetismo y mensaje positivo: Joaquín pide a Dios piedad para el rey, que es herido de muerte en la batalla y, moribundo, reconoce la grandeza del Dios de los judíos:

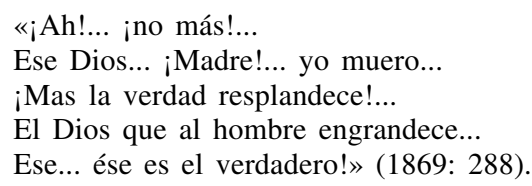

Mientras Daniel profetiza no sólo la reconstrucción del templo de Dios, sino el advenimiento del Mesías, poniendo el colofón a la victoria de los «valores judeo cristianos frente al materialismo pagano de la corte de Baltasar.» (Ripoll y Valdespino, 1973: 226).

\title{
COMPOSICIÓN DE BALTASAR COMO DRAMA ROMÁNTICO ESPECTACULAR
}

El conflicto del monarca, que sale por un momento del hastío vital, por la fuerza del amor, para ver corroborado su escepticismo en cualquier valor humano y despeñarse en el dolor y la soledad hasta la muerte, encuentra su forma dramática en una estructura equilibrada (apropiada para la visión armoniosa que pretende transmitir), que acoge constantes y apasionados enfrentamientos ideológicos sostenidos por el monarca con el resto de personajes principales del 
drama; la obra se traza con un esquema fulgurante de ascenso y caída y con una concepción espectacular y «teatralizante» del proceso que experimenta Baltasar, muy tenida en cuenta por la autora y reflejada en sus acotaciones.

Gómez de Avellaneda dispone la materia de su Baltasar en cuatro actos, cuya acción sucede en lugares distintos, con una clara contraposición entre la prisión de Joaquín («lúgubre estancia») y el palacio de Baltasar, mostrado en su esplendor. Como he apuntado, el afecto de Rubén y Elda hace que la mazmorra sea para ellos un lugar amado, mientras que su suntuoso palacio será una cárcel espiritual para Baltasar, el lugar que le recuerda constantemente quién es y lo reduce a su soledad y hastío. El segundo acto pretende que el teatro reviva el hechizo nocturno de los jardines del palacio de Babilonia, sin escatimar en componentes de decoración («fuentes, obeliscos, estatuas, etc.», ni en la iluminación («profusamente iluminados»), ni en su grandeza («por entre alamedas en que se pierde la vista»), ni en figuración («aparecen grupos de mujeres ataviadas con magnificencia, que templan instrumentos músicos, tejen guirnaldas, y queman perfumes en pebeteros de oro.»; 1869: 320). La entrada de Baltasar en escena — momento de gran importancia para la obra está cuidada de forma especial por la autora. Después de indicar cómo han de disponerse por el escenario, en laterales y fondo, la comitiva que precede al rey, sus cortesanos y esclavos, sus esclavas y las damas de la reina - entre las que ya está Elda-, Gómez de Avellaneda dispone una entrada espectacular del monarca:

(Rompe una música suave, que se supone de cítaras y otros instrumentos que tañen las esclavas, mientras várias de ellas esparcen perfumes, y otras se adelantan con cadenciosos pasos, al compas del himno que entonan las demas, formando en el centro graciosas figuras y mudanzas, y entrelazando guirnaldas, que al fin de la danza rinden á los piés del rey.- Baltasar entra con su madre al comenzar el himno; atraviesa la escena y va á sentarse en el divan dispuesto para él, ocupando Nitocris su izquierda.- Todos se inclinan profundamente al entrar el rey.) (1869b: 326).

que, lejos de ser ociosa o una mera concesión a lo espectacular, sirve para que se manifieste con vigor el estado espiritual del rey, que ordena con cansancio que cese el himno que lo alaba, desbarata con un puntapié las guirnaldas y ordena que se vayan las mujeres y arrojen de allí esas flores («iTanto incienso me sofoca!»; 1869:327) y, aunque accede a que la fiesta continúe, es para lamentar amargamente la falta de novedad y atractivo en su mundo, donde, por el contrario sólo halla degradación.

Para el tercer acto, Gómez de Avellaneda dispone otro cambio de lugar, llevando la acción a un salón del harén («decorado al estilo oriental»), que comunica por el foro con una plaza de la ciudad, desde la que accederá al final del acto el populacho exaltado que acabará con la vida de Rubén. Antes, la autora cuida de ir haciendo manifiesta la presencia de los descontentos, me- 
diante el rumor cuyo comienzo se hace coincidir, de forma efectista, con la decisión de Baltasar de otorgar la máxima dignidad a Rubén, y que van acrecentándose hasta convertirse en «alaridos» que molestan al rey, hasta que los hace entrar en el vestíbulo; entonces, Gómez de Avellaneda dispone un movimiento afectuoso de Elda hacia Rubén, «como para protegerle contra el furor que se anuncia» (1869:359), mientras «una multitud» debe invadir el vestíbulo, y arrollar a Rubén al final del acto.

La espectacularidad alcanza su altura máxima en el cuarto acto, en el que se ha de producir el prodigio de la mano avisadora y el desenlace devastador para Baltasar y su reino. La acotación inicial dispone un nuevo lugar, más espléndido todavía que el del segundo acto, el salón del banquete, "adornado con magnificencia y resplandeciente de luces», con trofeos guerreros y guirnaldas de flores en los muros, con pebeteros «de oro y plata» en los que arden aromas; salón que se abre al jardín aéreo, con sus estatuas y fuentes, y que deja ver al fondo las «cúpulas y torres de Babilonia»; en un decorado que, además, ha de estar dinamizado por la luz de los relámpagos y el sonido de los truenos que han de hacerse más notorios a medida que avanza la acción («desde el momento en que concluye la tercera escena», precisa la autora), mezclados con la música que suena en el jardín, en una amalgama bien significativa. La escena estará, de nuevo, poblada por numerosas gentes: sátrapas, mujeres del rey, esclavos que sirven la mesa, músicos...

Toda esta escenografía está dispuesta, desde luego, para desembocar en el momento del prodigio divino, que la autora dispone así en su acotación, tras el brindis sacrílego de Baltasar:

Los cortesanos, ebrios, sueltan una carcajada, y al ir á llevar las copas á los labios, una ráfaga violenta de viento abre de golpe todas las ventanas y puertas del regio salon, derribando las estatuas de los pedestales y apagando instantáneamente las luces. La música cesa; las copas sagradas caen de las manos de los sacrílegos; y entre la oscuridad y el estupor general, al estampido de un gran trueno, aparece al frente del rey, con caractéres de fuego, el célebre letrero histórico: Mane, Thecel, Phares. Todos se apartan de la mesa, despavoridos. (1869b: 382).

Magos y sátrapas expresan con exclamaciones su terror y confusión; Baltasar exige que le revelen el significado del prodigio pero todos sus adivinos se declaran impotentes, siendo Daniel quien hace la interpretación, terrible para el rey y su imperio.

La espectacularidad, alta ya en este momento, sube de nivel todavía más, al disponer la autora un final a sangre, conversión, profecía y fuego. Así en el momento en que Daniel rechaza el manto real que le ofrece el rey y Baltasar amenaza con aniquilar al pueblo de Sión si la profecía de Daniel no se cumple ese mismo día, Rabsares llama al arma por la llegada de Ciro y culpa a Nitocris de imprevisión, por haber dado la idea a Ciro de desviar el cauce del río, encontrando así paso franco a la ciudad. Baltasar, desoyendo los ruegos de su 
madre de que huya (por no arrostrar la cólera de un Dios), se arma y sale a la batalla y Nitocris, transida de dolor, pide a Daniel que suplique a su Dios misericordia para su hijo, ofreciéndose ella en lugar de su hijo para aplacarlo y Joaquín y Daniel, en apartes, contrapuntean el dolor de la madre: «iCuál vengas, Señor, tu gloria!» (386), mientras se oye el ruido cercano de la lucha y Rabsares entra huyendo y refiere la lucha y derrota del rey, al que entran moribundo con la vida justa para reconocer la grandeza del Dios de los judíos y caer en brazos de su madre, quien viendo a los enemigos a las puertas del palacio, anuncia que no dejará que los invasores huellen los despojos de su hijo ni sus propios ojos habrán de contemplar el baldón del cetro asirio y acude al interior del palacio para incendiarlo. Daniel hace la profecía del advenimiento del Mesías y Nitocris vuelve para arrojarse sobre el cadáver de su hijo, mientras se ven las llamas que devoran lo interior del palacio, y aparecen los vencedores por el foro, alumbrados por el incendio.) (1869b: 389).

Responde también a la sensibilidad romántica todo el episodio en el que Elda, perdida la razón tras la muerte atroz de Rubén, hace su aparición en el banquete con que Baltasar trata de olvidarla y borrar de sí lo que fueron sus engañosas ilusiones.

Como ya he dicho, así, con esta configuración romántica, viene a completar el recorrido dramático que comenzó como muchacha dulce y tierna al comienzo del drama, para pasar a encarnar el tipo de mujer fuerte de la Biblia en su primera presencia ante Baltasar, y termina en esta configuración romántica. La acotación prevé para ella una aparición impactante: «desmelenada, el vestido en desorden, y pintado en todo su aspecto el extravío de la razón», y su delirio busca mostrar el doloroso efecto de la crueldad en un alma sensible y sencilla, al tiempo que una visión premonitoria que se adelanta, incluso, al prodigio de la mano profética, y a la que Gómez de Avellaneda da gran importancia, al punto de que indica que debe ser tenida en cuenta para regir la actuación de la actriz, trascendiendo con ello lo que podría no ser sino un caso (más) de locura por amor y dolor ${ }^{34}$. En su trastorno, Elda se instala por un momento en el instante en que Rubén todavía estaba vivo, y su petición de clemencia al rey hace más lacerante y dramático lo sucedido. Al tiempo, es eficaz y efectista la transición brusca con que pasa a referir la visión de una realidad tétrica y mortal allí donde todos ven la pompa del palacio y la alegría del banquete. Gómez de Avellaneda está muy atenta a la puesta en escena de este momento especial y cuida tanto el movimiento y el gesto de

${ }^{34}$ Así, indica, en nota: «Para caracterizar bien cuanto dice Elda en esta escena, debe tener presente la actriz encargada del papel, que no hay aquí un simple delirio, sino una intuición misteriosa de la grande y próxima catástrofe. En medio de aquella pompa régia, de aquella delirante alegría, el monarca ateo, condenado por el cielo, va á hundirse para siempre con su imperio, con la corrompida sociedad que representa; y Elda, su víctima, anuncia ya, aunque con la exaltación de la demencia, aquel gran suceso providencial, sintiendo — por decirlo así- el olor de la muerte entre los perfumes del festín. (1869b: 378). 
Elda ( «Se suspende como escuchando la música, pero de repente se oscurece su rostro y parece poseída de espanto»), como la coreografía — por así decir del conjunto ( El rey, que atiende con semblante sombrío, se le va acercando maquinalmente; los cortesanos le imitan.»; 1869: 377). Su discurso responde al tópico de lo tétrico del romanticismo, con el recurso al frío, las tinieblas y el espanto y la contraposición del palacio y el cementerio («iPensé hallarme en un palacio.../ Y es un vasto cementerio!»; 1869b: 378), y el diálogo con los espectros, a los que pide que la dejen vivir, que no le señalen su sitio entre los yertos despojos, que ella es joven y es querida, hasta que «Suspendiéndose, como si oyera algo que la horroriza»; 1869b: 379, e intentando huir, se encuentra con Baltasar y cae en la cuenta de la terrible realidad: tras gritar «i $i$ No!! ¡ya es tarde! ¡ es tarde!!...», «Cae desplomada en tierra»; (íd.), de donde el rey ordena que se la lleven.

El Baltasar de Gómez de Avellaneda es una pieza digna y acertada en lo sustancial, con situaciones y enfrentamientos vigorosos y reveladores, que cuajan a veces en parlamentos vibrantes, cargados de emoción, sobre la razón de ser de la existencia, los afectos, el gobierno y la creencia religiosa.

Un detalle de buena dramaturga es el hecho de que Gómez de Avellaneda entienda el valor del silencio y que lo haga valer en determinados momentos de su obra, para acrecentar el suspense, como en el comienzo de la escena quinta del segundo acto, después de que Elda haya desafiado al rey, al negarse a cantar; del tumulto y algarabía se pasa a la intimidad de los dos y la acotación señala: Momento de silencio. Baltasar se sienta. (1869b: 335). Algo parecido sucede cuando Rubén ataca al rey para evitar que abuse de Elda; Baltasar, conmovido por haber comenzado a sentir, ordena a sus guardias que se retiren y la acotación señala que Rubén mismo, atónito de la acción del rey, y sin acertar cuál puede ser su intención, se queda suspenso. (1869b: 339), con lo que termina la escena.

Y también es revelador de buen hacer el interés con que Gómez de Avellaneda pauta la actuación de Baltasar en el cuarto acto, señalando las distintas disposiciones que el rey debe mostrar. El comienzo del acto lo presenta "echado en el diván, parece entregado á sombría cavilación, y se estremece, como despertando de un sueño penoso, á las primeras palabras de la reina.», a la que replica «con desaliento doloroso», para afirmar la única realidad del dolor, traicionada su esperanza «traidora» (1869b: 364), como «humo leve», «ilusión de un sueño breve» (íd.), para concluir manifestando, "con ironía acerba», su inútil esperanza de que el festín le conforte el alma, aunque apremia a Neregel para que el banquete lo haga olvidarse de sí mismo; a continuación replica «con sarcasmo» a Daniel, enumerando los males del mundo y atribuyéndoselos a «Esa Providencia sabia/ Á que das culto sumiso» (1869b: 369), pasando a escucharlo «desdeñosamente». De este desdén y del frenesí del banquete lo saca la presencia y el desvarío de Elda, a la que «atiende con semblante sombrío», y a la que «se va acercando maquinalmente» (1869b: 
377). Una vez sacada del salón, Elda, la acotación indica que Baltasar ordene que siga el banquete «queriendo sacudir su remordimiento y con animación febril, que va aumentándose hasta rayar en vértigo» (1869b: 380), en el cual exige los vasos sagrados del templo de Salomón para hacer su brindis sacrílego, respondido por el prodigio, que llena de pavor a todos los cortesanos, pero no al rey (siendo así que la Biblia era explícita y muy expresiva al referir los signos del temor de Baltasar), que cuando siente espanto, a su pesar, es con la llegada de Daniel; temor que se traduce en la amenaza de aniquilar al pueblo de Sión si la profecía de Daniel no se cumple ese mismo día, algo que no podrá hacer porque de inmediato sale a la batalla donde será herido de muerte, de donde volverá para manifestar la verdad del Dios de los judíos, con un gesto dramático y teatral, al expirar: Hace un esfuerzo para incorporarse al confesar á Dios, y vuelve á caer en brazos de su madre. (1869b: 388) ${ }^{35}$.

En lo negativo de la obra, cabe apuntar la distancia que hay entre el personaje de Baltasar y el resto, y la relativa inverosimilitud en que se funda la trama; pero, sobre todo, flaquea en ella su resorte movilizador que, a su vez, se convierte en una acción secundaria. La autora ha dispuesto a tal efecto una intriga urdida por altos dignatarios de la corte de Baltasar que conspiran contra Nitocris, a quien no aceptan como regente, por ser mujer y son quienes la animan a integrar a Elda en su séquito, con la finalidad de que el rey, al verla y al saberla virtuosa, pueda tener un motivo para salir de su apatía, lo que desencadenará todo el conflicto posterior.

Sin duda es el componente más endeble del drama, tanto porque las figuras que la impulsan, Rabsares y Neregel, no alcanzan en ningún momento la consistencia adecuada, como porque tampoco tiene consistencia que quieran despertar al rey por el amor, para que después vuelva a adormecerse en este sentimiento como antes lo estaba en el del hastío, pero ahora (¿por qué?) «dejando rodar su cetro: «Yo estoy cierto/ Que en los brazos del placer,/ Lo mismo que en los del tedio, / Se adormirá el soberano/ Dejando rodar su cetro.» (1869b: 346).

\section{REFERENCIAS BIBLIOGRÁFICAS}

\section{Obras literarias}

BAUDELAIRE, Charles. Las flores del mal. Edición bilingüe de Alain Verjat y Luis Martínez de Merlo. Madrid: Cátedra, 1995.

BYRON, Sardanapalus. En Selected Poems. Edited with a preface by Susan J. Wolfson and Peter J. Manning. London: 1996, pp. 635-734.

${ }^{35}$ No muere, pues, «en manos del pueblo», ni «en» ni «a», como quiere Gies, (1996: 283), ya que muere luchando contra los persas de Ciro que invaden su ciudad y expira en brazos de su madre. 
CALDERÓN DE LA BARCA, Pedro. La cena de Baltasar. Edición digital a partir de la de Pedro del Pando y Mier. Autos Sacramentales, alegóricos y historiales.... Tercera parte. Madrid: Manuel Ruiz de Murga, 1717 y cotejada con la edición de Nicolás González Ruiz (Piezas maestras del teatro teológico español. Madrid: Biblioteca de Autores Cristianos, 1997, $4^{\text {a }}$ ed. t. I, pp.342-368; $1^{\text {a }}$ ed. 1947.).

ESPRONCEDA, José de. Poesías líricas. El estudiante de Salamanca. Madrid: Espasa-Calpe, 1975.

GÓMEZ DE AVELlANEDA, Gertrudis. Saúl. Drama bíblico. En cuatro actos y en verso. En Obras literarias. Tomo 2, Obras dramáticas. Madrid: Imprenta y Estereotipia de M. Rivadeneyra, 1869a, pp. 209-292.

- Baltasar. Drama oriental. En cuatro actos y en verso, en Obras literarias. Tomo 2. Obras dramáticas. Madrid: Imprenta y Estereotipia de M. Rivadeneyra, 1869b, pp. 293-389.

—. Obras. Castro y Calvo, José Ma (ed.). Madrid: Atlas (1974-1981), 5 vols. BAE CCLXXII, CCLXXVII, CCLXXX, CCLXXXVIII.

La Biblia. Traducción totalmente revisada, con amplias notas e introducciones. Edición aprobada por la Conferencia Episcopal Española. Madrid: Atenas, PPC, Sígueme, Verbo Divino, 1992.

ZORRILLA, José. Don Juan Tenorio. Introducción Francisco Nieva, Madrid: Espasa-Calpe, 2002.

\section{Estudios}

ALONSO CORTÉS, Narciso. «El teatro español en el siglo XIX». En Historia general de las literaturas hispánicas. Díaz-Plaja, Guillermo (dir. de publicación). Barcelona, Vergara, 1968, pp. 284-286. Vol. IV. Siglos XVIII y XIX, Segunda parte,

ARROM, Juan José. Historia de la literatura dramática cubana. Yale: University Press, New Haven, 1944.

BANUSCH, Susanne. «Baltasar, de la Avellaneda». Cuadernos Hispanoamericanos. Madrid, 1996, 548 pp. 121-129.

BRAVO-VILLASANTE, Carmen. Una vida romántica. La Avellaneda, Madrid, 1967.

CALDERA, Ermanno. Il drama romántico in Spagna. Pisa: Universidad, 1974.

- El teatro español en la época romántica, Madrid: Castalia, 2001.

—. y CALDERONE, Antonieta. «El teatro en el siglo XIX (1808-1844)». En Díez Borque, José $\mathrm{M}^{\mathrm{a}}$ (ed.). Historia del teatro en España. Madrid: Taurus, 1988. vol II.

CANTERO GARCÍA, Víctor. «Estudio y análisis de los ideales feministas de Gertrudis Gómez de Avellaneda: tratamiento e importancia de los personajes femeninos de sus dramas». Cuadernos para la investigación de la Literatura Hispánica. Madrid, 2003, 28 pp. 361-379.

CAPELLÁN DE LA CRUZ, Jesús Antonio. «6. El teatro». En Pedraza Jiménez, Felipe B. (coord.). Manual de la literatura hispanoamericana. II. Siglo XIX. Berriozar (Navarra): CENLIT Ediciones, 1991, pp. 477-481.

CARNERO, Guillermo. Los orígenes del romanticismo reaccionario español. Valencia: Universidad de Valencia, 1978.

COTARELO Y MORI, Emilio. La Avellaneda y sus obras. Ensayo biográfico y crítico. Madrid: Olózaga, 1930.

DOMÉNECH, Fernando. «II.13.7. Otros autores». En PENAS VARELA, Ermitas.«El drama romántico». Huerta Calvo, Javier (dir.); Doménech Rico, Fernando y PERAL VEGA, Emilio (coords.). Historia del teatro español. II. Del siglo XVIII a la época actual. Madrid: Gredos, 2003, pp. 1925-1937.

GARCÍA LORENZO, Luciano. «La denominación de los géneros teatrales en España durante el siglo XIX y el primer tercio del XX». Segismundo 3, 1967, pp. 191-199. 
GIES, David. El teatro en España en el siglo XIX [1994]. Cambridge: Cambridge University Press, 1996.

—. «El teatro clasicista durante el reinado de Fernando VII y el Romanticismo». En Historia de la literatura española. García de la Concha, Víctor (dir). Vol. 8, Siglo XIX (I); Carnero, Guillermo. Madrid: Espasa-Calpe, 1997, pp. 293-313.

GONZÁLEZ SUBÍAS, José Luis. «Gertrudis Gómez de Avellaneda y la tragedia romántica española». En Lectora, Heroína, Autora (La mujer en la literatura española del siglo XIX). III Coloquio de la Sociedad de Literatura Española del siglo XIX. (Barcelona, 2325 de octubre de 2002). Edición de V. Trueba [et al.]. Barcelona: Universitat de Barcelona, PPU, 2005, pp. 173-183.

GUTIÉRREZ, Fabián. «La configuración del personaje en Baltasr, de Gertrudis Gómez de Avellaneda». Teatro: Revista de estudios teatrales, 1995, pp. 201-212. nº 6-7.

HERRERO, Javier. «Romantic theology: love, death and the beyond». En Rosenber, John D. (ed.). Resonancias románticas. Madrid: Porrúa Turanzas, 1988, pp. 1-20.

LAGUERRE, Enrique. «La mujer en las tragedias de Gertrudis Gómez de Avellaneda». En Homenaje a Gertrudis Gómez de Avellaneda. Zaldívar, Gladis; Martínez de Cabrera, Rosa (eds.). Miami: Ediciones Universal, 1981, pp. 183-199.

LEAL, Rine. Breve historia del teatro cubano. La Habana: Edición Letras cubanas, 1980.

MESONERO ROMANOS, Ramón de. Memorias de un setentón. Barcelona: Crítica, 2008.

RAGGI, Carlos M. «Influencias inglesas en la obra de Gertrudis Gómez de Avellaneda». En Homenaje a Gertrudis Gómez de Avellaneda. Zaldívar, Gladis; Martínez de Cabrera, Rosa (eds.). Miami: Ediciones Universal, 1981, pp. 37-49.

RIBAO PEREIRA, Montserrat. «La locura femenina como resorte espectacular: obnubilación, delirio y demencia en el drama romántico». Letras peninsulares, 1999, 12, pp. 185199.

RIPOLL, Carlos; VALDESPINO, Andrés. Teatro hispanoamericano. II. Siglo XIX. Nueva York: Anaya Book Co., Inc., 1973.

ROLDÁN, Amalia. «Tiempos modernos y la pervivencia de los viejos modelos. Tipos femeninos en Baltasar de Gertrudis Gómez de Avellaneda». En VII Encuentro de la Ilustración al Romanticismo: Cádiz, América y Europa ante la Modernidad. La mujer en los siglos XVIII y XIX. Cádiz, 19-21 de mayo, 1993. Canterla, Cinta (coord.). Cádiz: Universidad de Cádiz, 1994, pp. 589-597.

RUIZ RAMÓN, Francisco. Historia del teatro español (Desde sus orígenes hasta 1900), Madrid: Cátedra, 1979.

SÁNCHEZ-LLAMA, Iñigo. «Baltasar (1858), de Gertrudis Gómez de Avellaneda (18141873): Análisis de una recepción institucional». Hispanófila. Chapel Hill, NC, 2001, 133, pp. 69-94.

SEBOLD, Russell P. «Sobre el nombre español del dolor romántico». El rapto de la mente. Poética y poesía dieciochesca. Barcelona: Anthropos, 1989, pp. 157-169.

SHAW, Donald L. «El drama romántico como modelo literario e ideológico». HLE XIX (I), 1997, pp. 314-351.

—. Historia de la literatura española. El siglo XIX. Madrid: Ariel, 1981, pp. 62-65.

VILLAVERDE, Luis G. «Gertrudis Gómez de Avellaneda, dramaturga ecléctica». En Homenaje a Gertrudis Gómez de Avellaneda. Zaldívar, Gladis; Martínez de Cabrera, Rosa (eds.). Miami: Ediciones Universal, 1981, pp. 200-209.

ZALDÍVAR, Gladis; Martínez de Cabrera, Rosa (eds.). Homenaje a Gertrudis Gómez de Avellaneda. Miami: Ediciones Universal, 1981.

Fecha de recepción: 17 de diciembre de 2008

Fecha de aceptación: 1 de julio de 2009 